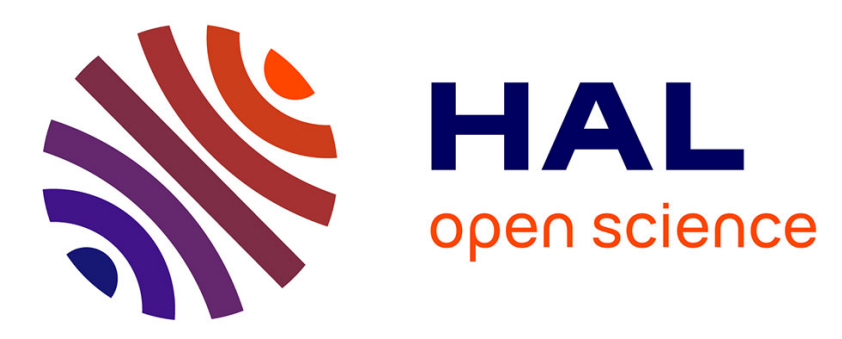

\title{
Italian Mathematicians and the First World War: Intellectual Debates and Institutional Innovations
}

Pietro Nastasi, Rossana Tazzioli

\section{To cite this version:}

Pietro Nastasi, Rossana Tazzioli. Italian Mathematicians and the First World War: Intellectual Debates and Institutional Innovations. David Aubin, Catherine Goldstein. The War of Guns and Mathematics, American Mathematical Society, pp.181-228, 2014, 978-1-4704-1469-6. hal-01448840

\author{
HAL Id: hal-01448840 \\ https://hal.science/hal-01448840
}

Submitted on 7 Feb 2017

HAL is a multi-disciplinary open access archive for the deposit and dissemination of scientific research documents, whether they are published or not. The documents may come from teaching and research institutions in France or abroad, or from public or private research centers.
L'archive ouverte pluridisciplinaire HAL, est destinée au dépôt et à la diffusion de documents scientifiques de niveau recherche, publiés ou non, émanant des établissements d'enseignement et de recherche français ou étrangers, des laboratoires publics ou privés. 


\title{
Italian Mathematicians and the First World War: Intellectual Debates and Institutional Innovations
}

\author{
Pietro Nastasi and Rossana Tazzioli
}

Abstract. Abstract???

\section{Introduction}

While Italian historical bibliography dealing with the Great War is extensive, secondary literature on Italian scientists' involvement in the conflict is very sarce. Compared to other European nations, Italy lacks a set of historical studies, critically and systematically organized to make better sense of the role of its scientists - let alone, its mathematicians - during the First World War. ${ }^{1}$ This article is meant to provide a first approach to the question of Italian scientists' involvement in World War I. We focus especially on mathematicians' actions, although these may not always concern mathematics exclusively nor even directly.

Our preliminary survey leads us to identify three moments where Italian mathematicians' involvement with WWI was consequential. First, during what we call the Interlude period - from the declaration of war between the Great Powers in August 1914 to Italy's decision to enter the battle on the Allied side on 25 May, 1915 - debates regarding intervention were intense among Italian intellectuals. In these debates, mathematicians partook and expressed a broad range of opinions, which, as we will hint at, were significantly shaped by their prewar international networks of relations. We will also see that while some mathematicians sticked to their beliefs for the whole duration of the war and indeed much after, others drastically revised them due to the pressure of the events.

In a second part, we survey Italian mathematicians' mobilization during the active phase of WWI. The first thing to point out is that like in other countries the majority of Italian scientists got involved in the war simply as citizens, the

\footnotetext{
1991 Mathematics Subject Classification. Primary ???; Secondary ???

${ }^{1}$ Omitting the large production of war memories by Italians mobilized in the army, let us mention the following books: [Isnenghi 1989], [Isnenghi 1993], [Fabu 1994], [Tomassini 1995], [Isnenghi 1996-1997], [Gibelli 1998], and [Isnenghi \& Rochat 2000]. On Italian mathematicians and WWI see [Guerraggio \& Nastasi 2005], chapters 2 \& 6. Other countries seem to have been better documented: see for example [Dauben 1980], [De Maria \& Seidel 1980], [Hartcup 1988], [Roussel 1989], [Pestre 1990], [Aubin \& Bret 2003], and [Goldstein 2009]. Overview about the connection between mathematics and war can be found in [Fieschi 1987], [Fieschi \& Paris De Renzi 1995], and [Booß-Bavnbek \& Høyrup 2003]; see in particular [Siegmund-Schultze 2003].
} 
youngest serving in active units of the army. Gradually, however, many scientists started to engage in collaborations with military institutions and developed bonds with the military and industry, which would take a whole new dimension twenty years later. Late comers to this scientific war, Italians were able to take cues from their allies' experience. But although they participated in international initiatives, the structuration of Italian war-related research was rather slow, at least as far as the institutional level was concerned. In the end, one remains under the impression that, although some achieved impressive results, successful instances of mathematical mobilization owed more to special circumstances than to overall planification. Even if institutions intended to favor "inventions and research" were created during the war, scientists there often had a role that was secondary, in the sense that they were usually asked to draft reports on projects proposed by others (inventors, militarymen, etc.), more than to carry out original research on their own.

Be that as it may, some mathematicians found their war experience very valuable and endeavored to shape some of their later activities accordingly. In the third part of our article, we focus on two especially blatant consequences of WWI in Italy at an institutional level: namely, the establishment of the National Research Council [Consiglio nazionale delle ricerche, $\mathrm{CNR}$ ] in 1923 and the Institute for the Application of Computing [Istituto per le applicazioni del calcolo, IAC] in 1927. It is significant that the mathematicians behind the foundation of both institutions, respectively, Vito Volterra (1860-1940) and Mauro Picone (1885-1977), also were key-figures who played different but exemplary roles in the mathematical and scientific mobilization of WWI. ${ }^{2}$ In 1917-1918, Volterra had been the head of the research board set up by the under-secretary for Arms and Munitions the Office for Inventions and Research [Ufficio Invenzioni e Ricerche, UIR], while Picone-who was 25 years younger - put together an noteworthy computing bureau for ballistics attached to Italy's Sixth Army. While the latter still occupied a marginal place in the Italian mathematical community before the war, Volterra already was a central figure in Italian politics and culture. In fact, as we will see, he was one of the most ardent partisans for Italian intervention before May 1915.

In what follows, we pay attention to the local mathematical culture in two principal ways. We take a look at the local mathematical culture in a few universities in Rome, Bologna, Turin, and Padua during the Interlude period. We moreover study changing institutional settings by considering extra-academic institutions such as - in addition to those already mentioned - the Mathematical Circle of Palermo [Circolo matematico di Palermo], the Central Institute of Aeronautics [Istituto centrale aeronautico, ICA], and the Italian Mathematical Union [Unione matematica italiana, UMI], where Volterra's and Picone's activities, of course, will be studied with attention. Due to the scarcity of articles and books on Italian mathematicians' involvement and role in WWI, we have wished as much as possible to let documents speak for themselves. Letters and reports here quoted at length are mainly kept in Italian archives. All unpublished material is provided both in original Italian (or French) with an English translation. ${ }^{3}$

\footnotetext{
${ }^{2}$ On Vito Volterra let us mention the following studies: [Goodstein 2007], [Guerraggio \& Paoloni 2008], [Paoloni \& Simili 2008], and [Mazliak \& Tazzioli 2010]. On Picone see for example [Fichera 1978] and [Tricomi 1977].

${ }^{3}$ We thank David Aubin for translating original material from the French.
} 


\section{Contributions by Italian Mathematicians to the Debate about Intervention}

Although Italy was a member of the Triple Alliance with the Central Empires, Germany and Austria, it officially remained neutral at the outbreak of the WWI. From the beginning of August 1914 to May 1915 when Italy finally declared war to its former allies, debates between "neutralists" and "interventionists" of various hues were very heated. In the following we survey this polemic and, especially, point out various mathematicians' attitudes with respect to intervention by considering some of the most representative Italian universities.

The particular position of Italy during WWI is of course rooted in the recent history of the country. Before 1860, Italy was divided into smaller states that were then united after a process called the Risorgimento, a popular movement that was both patriotic and democratic. Popular uprisings and two wars of independance with Austria led to unification in 1870 when Rome was proclaimed the capital of the new kingdom of Italy. In 1882 Italy signed the Triple Alliance together with Austria and Germany. This treaty, which guaranteed mutual support in case of aggression, was signed in spite of tense relations between Italy and Austria. Claimed by Italy the "terre irredente" (Trentino, Trieste, and Fiume) indeed remained in the hands of the Austro-Hungarian Empire. Despite this bone of contention, Italy joined the Triple Alliance because it feared a French aggression and because it wished to rely on Austrian and German protection to develop its own colonial empire in Africa. In 1882 Italy conquered part of Eritrea and in 1885 sarted a war of agression against Ethiopia. In 1911 Prime Minister Giovanni Giolitti declared war on Libya and then on Turkey. In 1912, Italy conquered some islands in the Aegean Sea and part of Libya. Meanwhile, however, a secret agreement was signed in 1902 between Italy and France guaranteeing neutrality of the former in case of a German aggression against the latter.

According to historians, Italian intellectuals generally supported Italy's intervention in WWI, as they did the colonial wars [Isnenghi 1989]. Some feared that by remaining neutral Italy was at risk of losing it status of Great Power, as well as any hope of recovering the terre irredente from Austria. Intellectuals also saw interventionism as a further break with the past fostering a progressive and anticlerical attitude. "We want to glorify war - the world's only hygiene" was famously proclaimed in the Futurist manifesto of 1909 printed on the front page of the French newspaper Le Figaro ([Apollonio 1973], p. 22).

1.1. Roman Scientists and Intellectuals: Volterra, Crocce, and Castelnuovo. Among scientists, Volterra came out strongly in favor of intervention. Succeeding Eugenio Beltrami as professor of mathematical physics at the University of Rome in 1900, Volterra had become one of Italy's most influential scholar. ${ }^{4}$ That same year, he pronounced his celebrated Prolusion aiming at promoting applications of mathematics to other sciences, especially to biology and economy. He also became ordinary member of the Academy of Lincei in 1899 and was elected Senator of the Kingdom in 1905.

\footnotetext{
${ }^{4}$ Graduating from the Scuola Normale of Pisa in 1882, Volterra had been appointed professor of rational mechanics at the University of Pisa in 1883 and to the university of Turin in 1892.
} 
Already then, Volterra embarked on various scientific enterprises devoted to create stronger connections between science and industry, which would have important repercussions after 1915 . Volterra played a prominent part in the foundation of scientific societies and institutions, such as the Italian Society of Physics [Società Italiana di Fisica] in 1897, the Italian Society for the Advancement of Science [Società Italiana per il Progresso delle Scienze, SIPS] in 1907, and the Italian Talassographic Committee [Comitato Talassografico Italiano] in 1910. Of special importance to this story, was, as we will see, his support he lent Arturo Crocco (1877-1968) in 1908 for the establishment of the Central Institute of Aeronautics, already mentioned.

But a crucial aspect of Volterra's prewar activities was his intense efforts at developing close relationships with French mathematics and culture. Contrary to an earlier generation that had mostly looked towards Germany, he strongly engaged in favor of cultural exchanges between Italy and France: exchanges of professors and of students, foundations of Italian institutes in France and French institutes in Italy, journals based on the cooperation between the two countries, propaganda in favor of Italian culture in France and vice-versa. ${ }^{5}$ He found in Julien Luchaire (1876-1962), a professor of Italian literature at the university of Grenoble, a French colleague who enthusiastically assisted him in this project. ${ }^{6}$ With Volterra's heavy involvement in creating closer links with France, it is no accident that nobody in the mathematical community argued as strongly as him in favor of an Italian participation to the war on the side of France, England, and Russia. He used his political, institutional, scientific and social relationships, developed during the prewar period especially with France, as an instrument for strengthening the support for intervention.

His exchanges of letters with Italian and foreign colleagues do not leave any doubt about his strong commitment to the cause. In a letter to Émile Borel (18711956), dated 14 September, 1914, Volterra called the Germans "the invaders" and remarked that "France is fighting for justice and for the cause of civilization against the violence of the most brutal and odious imperialism." 7 Many other letters by and to Volterra testify to his intense activity in favor of Italian intervention. This letter from Émile Picard (1856-1941) dated 5 September, 1914, is particularly evocative of the extreme opinions to which Volterra constantly answered with unwavering support:

I thank you for your warm wishes for the triumph of France over the Barbarians. [...] The German - I have always thought - is civilized only in appearence; in the smallest things he is coarse and without tact, and most often a compliment from a German becomes in an enormous blunder. Amplify this native coarseness, and you end up with the horrors we are seeing. Furthermore, he lacks honesty and uses a philosophical coating to excuse his crimes; it is time that this immense pride be taken down and that Europe be able to breath for the next century. All Europe should rise against the

\footnotetext{
${ }^{5}$ On this topic see Appendices 3 and 4 of [Mazliak \& Tazzioli 2010].

${ }^{6} \mathrm{His}$ book [Luchaire 1965] paints an interesting picture of Italian and French cultures in the period. On Luchaire and his relationship with Italy see [Renard 2002]. 37.

${ }^{7}$ Volterra to Borel, 14 September, 1914, VA:ADL; repr. [Mazliak \& Tazzioli 2010], p. 36-
} 
new Vandals that are only dreaming about putting the nation at its feet ([Mazliak \& Tazzioli 2010], p. 38).

In principle, most intellectuals shared with Volterra the opinion that a "democratic intervention" was called for on the side of the Entente and against "German barbarity." 8 But not all Italian intellectuals however were of the same opinion. The philosopher Benedetto Croce (1866-1952) expressed his discordant view in an interview published on 13 October, 1914, in the Corriere d'Italia. The polemics concerning the privileged relations of Italian culture with French or German thought were "manifestations of the state of war." He explained:

They are not rational questions but conflicts of passions; they do not deal with logical solutions, but with assertions of interests which, though lofty, are national, that is, particular; they are not proper reasoning but sham arguments based on imagination ([Croce 1950], p. 11-12).

Things taken for granted-like well-known statements by Volterra and other leading intellectuals insisting heavily on "German barbarity" - came under Croce's scrutiny:

I think that when the war stops, it will be found that the soil of Europe has trembled for months or for years not only under the weight of arms, but also under that of mistakes. And Frenchmen, Englishmen, Germans and Italians will be ashamed and will beg indulgence for the verdicts they have pronounced, and will say that these were not verdicts but expressions of passion. And even more shall we have to blush who, although they were from a neutral country, spoke of "German barbarity" as an obvious thing. Among all mistakes, $[\ldots]$ this one will hold the supremacy, since it is surely the most imposing one ([Croce 1950], p. 11-12).

According to a French witness, Croce considered himself a "Germanofilo" ([Luchaire 1965], vol. 2, p. 22). The Frenchmen also reported that Croce thought that to be on Germany's side was to uphold "the principle of authority" against "the abuses of freedom." But Croce was far from being alone as an Italian Germanophile. Many Italian scholars had studied and acquired specialized training in Germany; others simply liked the way its universities were organized or had a high esteem for German science. While many favored Italian neutrality, few went as far as arguing for participation to the war on the Central Empires' side. "Irredentismo" against Autria was too widespead a feeling. But, to name one, let us mention the chemist Giacomo Ciamician (1857-1922) who had studied at the university of Giessen. ${ }^{9}$ A member of the Academy of Lincei as well as senator, Ciamician wrote his colleague Volterra on 6 August 1914: ${ }^{10}$

\footnotetext{
${ }^{8}$ We may point out that while intervention was favored by most intellectuals, general opinion was more ambivalent. During the Interlude period, most people seemed to have backed neutrality while only a small minority was in favor of the Allies. A third position between the two called for an attack against Austria despite the treaty with the Triple Alliance. On this topic see [MacMillan 2001] and [Rusconi 2005].

${ }^{9}$ Other scholars are mentioned and discussed in [Simili 1993], p. 20-25.

${ }^{10}$ Let us note here that all letters from and to Volterra quoted in this article are kept in the Volterra Archive, Accademia dei Lincei, Rome (hereafter VA:ADL).
} 
What a mistake is this total war! It is an event that allows to think about nothing else. Where this can lead to, I wonder: it is an enormous disaster, a crime against civilization.

I cannot believe that everybody in Europe approves - and has wanted and wished for - this destruction. I hope that there exist some enlightened minds who will condemn this attempt on the lives and prosperity of the people.

I would believe that among scholars there would be some that would not be blinded by this excessive patriotic feeling that stirs up the most ferocious feelings of race and racial hate [...]

But, as far as I know, no voice has spoken in this sense.

Don't you think it would opportune for us to voice such a protest in the name of science which was offended because it does not know any difference of nationality? Don't you-who, beside the great authority of your name, is well-known abroad-think that it would be useful to know the opinion of the most important scholars of all countries? We hope that Italy can at the least stay neutral. ${ }^{11}$

Ciamiacian's intuition on racial hate is remarkable. This was a problem that became critical only after the war but was evidently rooted in prewar nationalistic feelings. Although Volterra, as we have seen, showed no sympathy toward Ciamician's appeal to scientific internationalism and his pacifist attitude and although most Italian mathematicians shared his views, some can be listed among neutralists or even among Germanophiles.

Among the Roman mathematicians who expressed anti-German views, we can also mention Guido Castelnuovo (1865-1952) then a professor at the university of Rome. With Federigo Enriques from Bologna, Castelnuovo was one of the foremost representatives of the so-called Italian school of algebraic geometry. After graduating from the university of Padua in 1886, he had spent a year in Rome and then became lecturer at the university of Turin, where he was influenced by Corrado Segre (who was in favor of Italian neutrality as we shall see in section 1.3). In 1891 he moved to Rome where he taught until his retirement.

Though less vocal than his friend and colleague Enriques (see section 1.2), Castelnuovo shared his attitude in favor of an Italian involvment in the war. In particular, Castelnuovo was convinced - as Enriques was - that pro-German propaganda was spread in Italy during the interlude period. On 31 July 1915, at

\footnotetext{
11 "Che errore questa guerra generale: è un evento che non permette di pensare ad altro. Chissà a cosa potrà condurre; è un disastro immane; un delitto contro la civiltà.

Io non posso credere che tutti in Europa approvino questa rovina e l'abbiano voluta e desiderata. Io spero che ci saranno delle menti illuminate che condanneranno questo attentato alle vite ed alle prosperità delle genti.

Io crederei che fra $i$ cultori delle nostre scienze ve ne saranno alcuni almeno non accecati da questo esagerato spirito patriottico che fa scatenare i più feroci sentimenti di razza e l'odio di razze $[. .$.

Peraltro a quanto io sappia nessuna voce s'è fatta sentire in questo senso.

Non credi tu che sarebbe opportuno farsi interpreti di una simile protesta in nome della scienza offesa, che non conosce differenze di nazionalità. Tu che oltre la grande autorità del tuo nome illustre, sei anche tanto conosciuto all'estero, non credi che sarebbe utile sentire in proposito l'opinione dei maggiori scienziati di tutti i paesi? Speriamo che almeno l'Italia possa restare neutrale" (Ciamician to Volterra, 6 August 1914, VA:ADL).
} 
a time when Italy had already declared war to Austria but not yet to Germany, Castelnuovo wrote to Volterra:

Concerning our relation with Germany, ambiguity unfortunately persists. Censure, which is clearly coming from above, purges newspapers from the sentences coming out too harshly against the Germans. [...] There are many symptoms, therefore, that we want to avoid becoming Germany's enemy.

Would it not be fitting that those Italian intellectuals who think more freely emphasize our war's high ideals according to which civilization should prevail in the world-ideals surely not inferior to those to which the government propaganda is nearly exclusively restricted? ${ }^{12}$

1.2. Interventionist Bologna: Pincherle and Enriques. Like their Roman colleagues, prominent mathematicians in Bologna seem to have come out rather strongly in favor of Italy entering the war. A professor of calculus at the university of Bologna since 1880, Salvatore Pincherle (1853-1936) was a staunch nationalist as well as an admirer of German mathematics. After his studies at the university of Pisa, he had spent the academic year 1877-1878 in Berlin where he met Karl Weierstrass who had a profound influenced on his subsequent work in the field of functional analysis. After the war, he supported the Fascist regime and had a influential position as first president of the newborn Italian Mathematical Union in 1922 (see below section 3.2), a position he kept for several years. Nationalistic as he was, he nonetheless embraced the cause of Italian intervention alongside with the Entente's Powers.

At a conference organised by Volterra in 1918 in Rome in memory of the Italian mathematicians who had fallen in war, Pincherle provided what we believed to be a faithful description of the tensions among various types of nationalism in the Interlude period. Referring to the infamous "Appeal of the 93 Intellectuals" ( $A n$ die Kulturwelt! Ein Aufruf) signed on 4 October 4, 1914, Pincherle wrote: ${ }^{13}$

Just after the fatal day on which the Central Powers suddenly revealed a project prepared for a long time and submitted the terrified world to a storm whose horrors surpassed the imagination, the most prominent German scholars, leaders of the army of science which was believed not to know any national border, threw off

\footnotetext{
12 "Purtroppo l'equivoco nei nostri rapporti colla Germania persiste. La censura, evidentemente ispirata dall'alto, va sopprimendo nei giornali le frasi troppo aspre verso $i$ tedeschi; [...] vi sono insomma molti sintomi che non vogliamo inimicarci la Germania.

Non sarebbe il caso che quella parte degli intellettuali italiani che pensa più liberamente, mettesse in rilievo le alte idealità della nostra guerra, riguardo alla civiltà che dovrebbe prevalere nel mondo, idealità certo non inferiori a quelle, a cui la propaganda governativa si è quasi esclusivamente ristretta?" (Castelnuovo to Volterra, 31 July 1915, VA:ADL).

${ }^{13}$ Also known as the Fulda Manifesto (after Ludwig Fulda, a well-known Jewish writer), the "Appeal" was signed by 93 high representatives of German art and scholarship and argued for their patriotic commitment in a very assertive key. Illustrious physicists, mathematicians, chemists signed the "Appeal" (such as Max Planck, Wilhelm Wien, Felix Klein, Walther Nernst, Fritz Haber, and others). The Manifesto was reinforced by two others, the first one signed by three thousand Faculty members of German universities and the second one by the Chancellors of twenty-two of them, all upholding the unassailable virtues of German culture. See [Gratzer 2000], in particular, chap. 8: "Science, Chauvinism and Bigotry."
} 
their masks just as did their rulers; and a famous Manifestowhich would have announced the true bankruptcy of science, had the ideas inspiring it prevailed - claimed that doctrines count only to the extent that they help the hegemonic ideas that German militarism was going to translate into reality.

And if in those days the large majority of our country's scientists were absolutely convinced that Italy could not stay away from the Great War, this was not only due to the intuition that neither now nor ever could Italy reclaim those territories that belonged to it by incontestable right, nor because the indefensible borders imposed by unjust treaties had to be corrected, nor because of the natural sympathy [we feel] toward the oppressed and menaced nations. It was also because the German Manifesto's ethical stance was against what was for us the supreme ideal of science; we had cultivated and venerated science at the condition that it should not become the monopoly of a race or the tool of a brutal power. We therefore felt that, should the enemy's evil plans prevail, everything we hoped and expected from science would have gone to waste.

In the heart of the noblest among our young brothers, this conviction was translated into action; they abandoned their favorite studies, the School where they could have continued without disgrace to render their services, in order to take up the arms: and if they fell in the battle, they left the most beautiful example and the most shining memory to their School. Among these noble minds we commemorate today several of our most famous mathematicians; and it is my task to evoke - alas with inadequate words - the figure of one of them, Eugenio Elia Levi [1883-1917] ([Collective 1918], p. 27).

Pincherle's colleague at the university of Bologna, Federigo Enriques (18711946) also supported Italian intervention on the Allies' side. With Castelnuovo, Enriques was one of the foremost representatives of the so-called Italian school of algebraic geometry. After studying in Pisa, Enriques had joined the university of Bologna in 1896, where he taught projective and descriptive geometry. Later, in 1923 he would move to the University of Rome, where he joined his friend and brother-in-law Castelnuovo.

Enriques shared his feeling about Italian intervention in his correspondence with Xavier Léon, the director of Revue de métaphysique et de morale. ${ }^{14}$ On 25 August, 1914, Enriques wrote:

I was in Switzerland, in Zurich, when the storm broke. [...] I spent hours in anguish before Italian neutrality was proclaimed; coming home to Italy, I understood that any other decision from the goverment would have been impossible, since the common feeling of Italians from all classes and all parties was unanimously against the agressors.

\footnotetext{
${ }^{14}$ Letters from Enriques to Léon and some drafts from Léon to Enriques are kept in the Xavier Léon Archive, Sorbonne Archive, Manuscripts of the Library V. Cousin in Paris (hereafter XLA:Sorbonne.
} 
If you could see the anxiety with which we wait here for news about the war and how the entire population hopes for France's salvation, you would be moved. For that matter, we feel here that this assertion of independence vis-à-vis Germany will be paid dearly in the case of a German victory.

We are now ready to be attacked, too. But if peace cannot be kept, let us be on the side of civility and right! This is the intimate thought of the whole Italian people whose calm and pacifism in fact merely hide our wish also to contribute ourselves - when the time will have come - to the enterprise of liberation. ${ }^{15}$

Polemics about Italy's position in the war caused personal troubles to Enriques, when he was forced to leave the direction of Scientia, the scientific and philosophical journal he had founded in 1907 and directed with Eugenio Rignano (1870-1930). Rignano had launched an inquiry, finding it inadmissible that a scientific journalas Scientia was - should shut itself up in an ivory tower and remain impassive toward the tragic events of the war. The inquiry was meant to achieve clarity about "the causes and factors of the war," but soon slid into the expression of personal opinions. At a moment when Italy had already entered the war, Rignano had no hesitation writing about the imperialistic aims of its British Ally and about the former's coresponsibility in bringing about the war. When Enriques asked Rignano to withdraw the opinion piece, and Rignano refused, Enriques left the direction of the journal with clamor - only to assume the directorship of Scientia again after Rignano's death in 1930.

Concerning Italian intellectuals' opinion towards the war, Enriques wrote to Léon on 4 February 1915:

About this war, no one knows well what to think. You know where lie our sympathies and aspirations; there is but a small number of people that do not share them (unfortunately Hegelian philosophy ${ }^{16}$ has not adopted an honorable position, it is among the small number of German sympatizers). But I believe that the Italian press fails to give a proper idea of the situation when it seems to be busy only with the alliance treaty. No one is quite sure about our obligations, but it is to be feared that the government itself is not entirely free, except in the case where Germans themselves

\footnotetext{
15 "Je me trouvais en Suisse, à Zürich, lorsque l'orage est éclaté. [...] J'ai passé des heures d'angoisse avant qu'on eut proclamé la neutralité italienne ; en rentrant en Italie j'ai compris que toute autre décision du gouvernement aurait été impossible, puisque les sentiments de tous les Italiens, de toutes les classes et de tous les partis, est unanime contre les agresseurs.

Si vous pouviez voir avec quelle anxiété on attend ici les nouvelles de la guerre et comment le peuple entier fait des voeux pour le salut de la France, vous en seriez touché. D'ailleurs on a ici le sentiment que l'acte d'indépendance accompli vis-à-vis de l'Allemagne, va nous coûter cher au cas où les Allemands seraient les vainqueurs.

On est préparés à être attaqués à notre tour ; mais si la paix ne peut être maintenue, que nous nous trouvions du coté de la civilité et du coté du droit! C'est là la pensée intime du peuple italien tout entier, dont la calme et le pacifisme ne cachent en somme que le propos de contribuer nous aussi - lorsque l'heure sera sonnée - à l'œuvre de libération" (Enriques to Léon, 25 August 1914, XLA:Sorbonne).

${ }^{16}$ The reference to the "philosophie hégélisante," dishonoured because of its pro-German ideas, was surely directed at Croce, whom we have already spoken about.
} 
would be foolish enough to attack our rights and become a menace. $^{17}$

1.3. Neutralist Turin and Padua: Segre, Severi, and Levi-Civita. We have already observed that some Italian intellectuals - though the minority - were neutralists. Even among mathematicians, not all agreed with the majority opinion championed by Volterra. As an example, let us mention Corrado Segre (1863-1924) at the university of Turin. One of the most influential geometers of his time, Segre is considered to be the founder of the Italian school of algebraic geometry. In a letter to Volterra, Carlo Somigliana (1860-1955) suspected Segre of pro-German neutralism. According to Somigliana, Segre's point of view was that war and its consequences should be ignored, except for "the due respect towards Germans." 18

When Segre learned that Hadamard wished to come to Italy to lecture on the theory of differential equations and waves, he believed that his true motives was to meet with mathematicians - such as Volterra - who were pro-war activists. That indeed happened some months later, in May 1916. We are informed of Hadamard's stay in Italy through his correspondence with Volterra, who had told Painlevé about his wish to get Hadamard to Rome for a lecture series. After some hesitation due to reluctance to interrupt his "war work," Hadamard came to Rome and held six lectures about "Partial Differential Equations and Related Problems Équations au dérivées partielles et problème aux limites qui s'y rattachent" in the first fortnight of May 1916. Of course Hadamard's lectures were also organized in order to tighten the bonds between Italian and French mathematicians. He moreover intended to discuss the problem "of the very strong opposition with which the pro-Allied movement is met by the Jewish population of the United States." ${ }^{19}$ Informing Volterra of actions taken by the French Jewish community to change this view, Hadamard expressed the wish that Volterra put pressure on the Italian government too.

Together with Castelnuovo and Enriques, Francesco Severi (1879-1961) was the third leading figure of Italian algebraic geometry. After an initial attitude promoting Italian neutrality, Severi adopted a position similar to Volterra's and Enriques'. Severi had also studied with Segre at the university of Turin. In 1914, he was professor of geometry at the university of Parma, where he was teaching since 1904. Later, in 1922, Severi would be appointed professor of algebraic geometry at the university of Rome. Thanks to his support to the Fascist regime, his academic and political career took a new turn: in 1923 he became chancellor of the university of Rome, in 1929 a member of the Fascist Academy of Italy, and in 1939 founded the National Institute of Higher Mathematics [Istituto Nazionale di Alta Matematica, INDAM].

\footnotetext{
17 "Quant à l'événement de cette guerre, personne ne sait bien à quoi s'en tenir. Vous savez quelles sont nos sympathies et nos aspirations, il n'y a peut-être qu'un petit nombre de personnes qui ne les partagent (malheureusement la philosophie hégélisante ne se fait pas honneur, elle est du petit nombre des sympathisant pour l'Allemagne). Mais je crois que la presse italienne ne donne pas une idée juste de la situation lorsqu'elle semble ne s'occuper guère du traité d'alliance. Personne ne connaît bien nos engagement, mais il est à craindre que le gouvernement ne soit pas entièrement libre, sauf dans le cas où les Allemands eux-mêmes commettraient la méprise d'attenter à nos droits ou de nous menacer" (Enriques to Léon, 4 February, 1915, XLA:Sorbonne).

${ }^{18}$ Somigliana to Volterra, 15 May 1916, VA:ADL.

${ }^{19}$ Hadamard to Volterra, 3 April 1916 (VA:ADL); repr. in [Mazliak \& Tazzioli 2010], p. 80; see also Appendix 2 in ibid.
} 
In Padua, Severi was already occupying administrative positions. He was director of the School for Engineers, the town-councillor in charge of education, a member of the commission for urban planning, and president of the municipal society for water and gas. A member of the Official Socialist Party ${ }^{20}$ Severi was a pacifist. He quickly changed his mind, however, to become a partisan of what Italian historiography has called "revolutionary intervention." Under this term, the interventionist stance of various branches of the revolutionary movement (socialists, anarchists, syndicalists,...) have been put together. ${ }^{21}$

In the newspaper L'Adriatico from 9 March 1915, Severi described his reasons for abandoning a neutralist position in favor of support for Italian war participation, although the Socialist Party's position was still firmly neutralist:

I hope and believe that in this crucial moment the attitude of the governing bodies of my party is an expression of that state of anguished tension, which any Socialist of reasons or heart feels, between the ideal imperatives of his own faith and his perception of the unavoidable needs of the present; and [that the party's attitude is] not the outcome of a thoroughly considered and methodically pursued plan for action.

But if it is so, and if it is also true, as I think, that the Socialist Party, as a political organization, could never support an intervention in war, I would find it rather preferable if the Socialist protest against the war remained, in any case, restricted to the purely ideal field, and if it was at the same time acknowledged that the actual situation is unescapable and cannot be modified today, precisely because it follows from social conditions that our Party cannot suddenly change. [...]

A less absolute attitude from our party's leadership would also be very important from a political point of view, since it would leave every party member free to evaluate the actual elements of the situation according to his own conscience as an Italian citizen and, at the same time, allow each of us to keep spreading Socialist propaganda to the masses by pointing out the monstrous disasters that follow from a capitalistic organization of society.

I am convinced of the necessity of an Italian intervention on the side of the Triple Entente. [...] It is true that the causes of this war are properly capitalistic, but we cannot ignore that because of the brutal violations of the natural rights of nations of which Germany is guilty, that because of the existence of many unresolved questions, and finally that because it is in the interest of some belligerent states, and especially of England, that minor nationalities be respected, [...] that because of all this, the war has on the whole developed into a battle between two conflicting visions of rights and forces that shall prevail in the modern world. ${ }^{22}$

\footnotetext{
${ }^{20}$ In the 14th Congress of the Italian Socialist Party taking place in Ancona in 1914, the revolutionary branch of the Party defeated the revisionist branch and became the "Official" Socialist Party.

${ }^{21}$ Is there a reference for the Italian historiography mentioned here???

${ }^{22}$ Severi, title of article???, L'Adriatico, 9 March 1915.
} 
Severi's colleague at the university of Padua, Tullio Levi-Civita (1873-1941) also was a Socialist. Appointed professor of mechanics at Padua in 1897, LeviCivita had studied there under first names??? Ricci, Curbastro, and Veronese. In 1918 he would move to Rome where he taught until 1938, when the Racial Laws were promulgated and he was forced to retire. One of the best Italian mathematicians of the period, Levi-Civita also enjoyed a high reputation abroad due to his research work on the three-body problem, tensor calculus, hydrodynamics, and general relativity theory.

Contrary to Severi, Levi-Civita remained a pacifist throughout the war. This considerably affected his friendship with Volterra: their correspondence, usually very amicable, became extremely formal during the war. As far as we know, LeviCivita never showed hostile feelings towards his German colleagues before, during, or after the war. From March to May 1915, he exchanged very interesting letters with Albert Einstein. Their main discussion concerned general relativity and strongly contributed to the correct expression for the gravitational field equations obtained by Einstein in November 1915. But Levi-Civita expressed his neutralism and pacifism whenever there was an occasion, and especially during the postwar period (see below section 3.1). He wrote to Arnold Sommerfeld (1868-1951) on 9 December, 1920:

I have always been, and not only in science, a convinced internationalist; and, on the basis of this ideal, I consider au dessus de la melée all nationalisms without exception [...]

However we agree on an essential point - and I am very pleased about it. We both believe that scientific and personal relationships between scholars from every country in general, and between us in particular, must not be disturbed in any case by circumstances or memories of national or state divergences. ${ }^{23}$

Levi-Civita's general hate of war and of its awful consequences is well expressed in a letter to George David Birkhoff (1884-1944) dated 23 August 1916:

As you may easily imagine, we are feeling in Europe much more than in America the depressing influence of war on scientific activities and collaboration: efforts, aspirations, young energies, and, generally, all forms of energy are mobilized by present circumstances; and unfortunately no symptom yet leads us to expect any time soon any kind of appeasement capable of insuring justice and reestablishing fraternity among the nations. ${ }^{24}$

In the end, however, Italian pro-war intellectuals were successful and, on 23 May, 1915, Italy officially declared war to Austria. Fifteen months later, on 27 August, 1916, it also declared war on Germany.

23 "Io sono sempre stato, non soltanto in scienza, un internazionalista convinto, e, in base a tale idealità, considero au dessus de la melée tutti indistintamente $i$ nazionalismi [...]

Però in un punto essenziale - e me ne compiaccio vivissimamente - ci troviamo in pieno accordo: nel convincimento che $i$ rapporti scientifici in genere e quelli personali tra gli studiosi d'ogni paese, e tra noi due in particolare, non debbano essere comunque turbati da contingenze o ricordi di divergenze nazionali o statali" (Levi-Civita to Sommerfeld, 9 December, 1920, Archive of Deutsches Museum, Munich.).

${ }^{24}$ Letters from Levi-Civita to Birkhoff are kept in Papers of G.D. Birkhoff, Harvard University Archives. Courtesy of Andrea B. Goldstein. The letters from Birkhoff to Levi-Civita are published in [Nastasi \& Tazzioli 2000], p. 199-220. 


\section{The Mobilization of Italian Mathematicians}

2.1. French Mathematicians' Reaction to Italian Intervention. Understandably, French mathematicians reacted to the Italian intervention with great enthusiasm. In an undated letter to Enriques, Léon lauded the "admirable" Italian decision to enter the war in spite of its dangers and horror. "There will not be," he added, "a German peace founded on an Empire extending from the Pyrenees to Ural: this is morally and historically impossible." ${ }^{25}$ On 26 May 1915, Picard wrote Volterra:

Your recent letter gave me a glimpse of the great event that just took place [the Italian declaration of war]. In France, we have seen with infinite joy Italy enter the great struggle of Civilization against Barbarity. The enemy is still strong, but he is wounded, and one is allowed to think that the staunch resistance it is putting up will suddenly weaken. Here, we consider that this gigantic struggle much surpasses the greatest wars of history. Enough ruins would have been accumulated and enough blood shed for Europe to enjoy peace for a long time to come. ${ }^{26}$

In a letter to Volterra dated 1 July, 1915, Hadamard clearly saw that Italian intervention in the war on the side of France should be the occasion for strengthening cooperation between mathematicians from both countries:

I have wanted to write to you for a long time, since I have learned through Pérès, and M. Richet, and many others how much pain and enthusiasm you gave to the great movement that is currently taking hold of Italy. The admirable élan of sympathy shown by our youth through the sacrifice of their life would have to be doubted if we refrained from honoring the occasion of remembering and tightening the links we have woven at a time when we were merely suspecting the boche Barbarity. ${ }^{27}$

"As for me," Hadamard added, "I make myself useful as I can - this is not muchby lending my help to a certain number of technical researches" (ibid.). Did, like the French, Italian intellectuals, and mathematicians in particular, also contribute to the war effort? We may say that, in spite of their great enthusiasm, Italian mathematicians - with the notable exception of Volterra and Picone-generally contributed at a personal, rather than formal, level.

2.2. Initial Stages of the Scientific Mobilization in Italy. All mathematicians who joined the army - and several indeed volunteered-were immediately made into reserve officers. Most made contributions to problems of external ballistics and of the connected field of telemetry. ${ }^{28}$ All of them were - at least at first-absolutely incompetent in ballistics; many of them certainly knew so-called

25 "Il n'y aura pas de Paix Germaine fondée sur un Empire qui s'étendrait de Pyrénées à l'Oural: cela est moralement historiquement impossible" (Enriques to Léon, undated, $\mathrm{XA}$ :Sorbonne, original emphasis)

${ }^{26}$ Picard to Volterra, 26 May, 1915, VA:ADL; repr. [Mazliak \& Tazzioli 2010], p. 55.

${ }^{27}$ Hadamard to Volterra, 1 July, 1915, VA:ADL; repr. [Mazliak \& Tazzioli 2010], p. 57.

${ }^{28} \mathrm{On}$ the Italian contributions to ballistics (mainly due to Fubini, Picone, Severi and Volterra), see [Tanzi Cattabianchi 1977], [Tanzi Cattabianchi 1981], and [Tanzi Cattabianchi 1988]. 
Galilean ballistics (external ballistics in empty space), whose first elements were taught in high schools and developed in the university course of mechanics. However, they were skilled mathematicians, able to face mathematical questions, and to work out useful solutions. As Pincherle noted in his obituary of E. E. Levi [Collective 1918], solid theoretical training easily allowed one to serve as a technician. This was true at least in the case of Leonida Tonelli (1885-1946), Luigi Tenca (1877-1960), Francesco Giacomo Tricomi (1897-1978), and E. E. Levi himself. $^{29}$ Significantly, however, even if the latter was one of the best scholars in complex analysis (according to [Dieudonné 1981], page???), he was modestly employed before he was killed in active duty, as a military engineer.

Let us also point out that none of them-at least if we are to judge from the silence of those working on this topic - asked for Levi-Civita's opinion. This is somewhat surprising when it is remembered that the latter might have been one of the very few mathematicians actually engaged in "terminal ballistics," before the war, with a study of the penetrating power of bullets in solid bodies [Levi-Civita 1906]. ${ }^{30}$ The only hint to that effect comes from Picone's commemoration of Levi-Civita:

I knew Tullio Levi-Civita in his hospitable house in Padua, during the war 1915-18. [...] I visited him from Schio, during the night, in a motor-lorry used for supplies. [...] He always received me cordially and studied with me some ballistic problems that I submitted to him. Out of these [visits], I always drew much profit in view of my various ballistic assignments. One day, he lent me a Brunswiga calculating machine which I had found on his desk [...]. This allowed us to make, in a short time, the long, difficult computations necessary for compiling the new firing tables [...]. I do not know where the calculating machine is now. Levi-Civita had the delicacy, natural to him, never to ask for it back ([Picone 1974], p. 21).

Generally speaking, Italy's military and institutional organization was very poor when it entered the war, compared with the other great powers. This was especially true with regards to the integration of science and technological innovation. France for example had set up a military Commission for examining inventions since 1894 [Roussel 1989]. Before the war the physicist Éleuthère Mascart (1837-1908), the chemist Henri Moissan (1852-1907), and the mathematician Paul Appell (1855-1930) were among its members. In 1914, at the very beginning of the war, the Commission changed its name to High Commission for Inventions Related to National Defense [Commission supérieure des inventions intéressant la défense nationale] and was reinforced by the presence of technicians, engineers, politicians, and academicians. It was headed by the mathematician Paul Painlevé (1863-1933) - replaced by Borel when the former became minister of War-and leading mathematicians (such as Borel, Hadamard, Henri Lebesgue, and Paul Montel) and physicists (such as Aimé Cotton, Paul Langevin, Jean Perrin, and Pierre

\footnotetext{
${ }^{29}$ War memories of some Italian mathematicians may be found in [Tenca 1959], [Terracini 1968], and [Tricomi 1967].

${ }^{30}$ Other interesting results in ballistics produced by Levi-Civita can be found in the following books he wrote in collaboration with the physicist Ugo Amaldi: [Amaldi \& Levi-Civita 1923-1927] and [Amaldi \& Levi-Civita 1935].
} 
Weiss) worked for it. The Commission had access to university and industrial laboratories, and was actively engaged in several problems involving the application of science applied to national defense (gas protection systems, improvement of firing tables, sound location of enemy batteries, detection of submarines, and so on).

Contrary to the United States, Italy seemed to have made no effort towards improving the scientific organization of military innovation before it entered the war. This much is acknowledged in a book about Italian "military culture":

just before [WWI], anxiety for renewal could be noticed in military organizations; it also concerned [military] culture: the formalization of practice had been replaced by lively interest for the military disciplines. For other reasons - financial difficulties, systematic oppositions on the part of certain currents of public opinion, governmental weakness - this much-needed process of renewal in the Italian Army was not as radical and deep as sould have been necessary to live up to our increasing status as great power ([Landogna 1937], vol. 3, p. 125).

Indeed, in spite of rapid progress in artillery techniques and doctrine made manifest during the first bloody months of WWI, old firing tables elaborated by General Francesco Siacci (1839-1907) thirty years earlier, were still in use. As Picone wrote in his papers on this subject (references???), in numerous cases Italian artillery fired at soldiers from their own side because they did not have sufficiently advanced firing tables. Later official documents also confirmed the "scarcity and inadequacy of our artillery" ([Landogna 1937], vol. 3, page???). ${ }^{31}$

Although the Italian mobilization of scientific resources thus took place in a generally disorganized manner, local structures were set up to foster technical and military innovation, such as the institutions created by Picone and Volterra. The National Committee for Inventions relating to War Materials [Comitato Nazionale per le invenzioni attinenti al materiale di guerra] was founded in July 1915 and officially recognized in March 1916 when it was delegated to represent Italy on the Inter-Allied Committee for Inventions [Comité interalliés des Inventions]. As we shall see, it was only between the end of 1916 and the beginning of 1917 that, thanks to Volterra, the Inventions and Research Office (UIR) was created following the French model.

Volterra traveled to France several times in order to visit the analogous French Commissions and also promoted Marie Curie's vist to Italy. Some years before the war, Volterra had asked Curie - without success - to take part in meetings of the Italian Physical Society (SIPS). Named director of UIR in 1917, Volterra renewed his invitation to Curie on behalf of the Italian government and this time she accepted. For nearly three weeks, from 30 July to 18 August, 1918, she toured Italian deposits of radium for medical and military uses. In the end, a report was drawn up, and it was decided to constitute a new Commission for Radioactive Materials attached to Volterra's UIR. ${ }^{32}$

\footnotetext{
${ }^{31}$ About French ballistics and how Siacci's methods were replaced by now ones, see David Aubin's contribution to this volume. The chapters by June Barrow-Green and by Thomas Archibald, Della Fenster, and Deborah Kent, respectively, discuss ballistic research in Great Britain and the US.

${ }^{32}$ See [Picone \& Bilinski 1969], p. 19. There is an unpublished report by Volterra that documents Curie's trip to Italy, VA:ADL.
} 
But Volterra was not dealing only with international scientific relations. Himself got his hand dirty working on technical devices as can be gathered from the following event reported by Giovanni Sansone (1888-1979), professor of analysis at the universities of Florence and Pisa:

During the First World War, I had the good fortune of being personally introduced to [Volterra] in April 1918 at Pero di Piave, where [as a reserve officer] I directed a "Cotton-Weiss phonotelemetric section," in charge of locating Austrian batteries positioned on the other side of the Piave along an eight-kilometer front. He served as Reserve Major in the Corps of Engineers; he had obtained instruments like mine from France and came to check whether the results obtained by my section were comparable to French ones, and indeed they were ([Sansone 1977], p. 30). ${ }^{33}$

Sansone's words clearly show that Volterra was in close scientific contact with his French colleagues, like for example those invloved in the computing bureau set up by Lebesgue and Montel. In Italy, the physicists Augusto Righi (1850-1920) and Antonio Garbasso (1871-1933), together with Severi, were the main scientists involved in phonotelemetric measurements. On this subject a heated controversy between French and Italian scientists broke out, which can be used to show how the latter failed to be integrated in a complex military-scientific coordinated ensemble. $^{34}$

The unsystematic nature of Italian scientific mobilization however suffered some rare exceptions. The war work carried out by the Institute of Pharmaceutical and Toxicological Chemistry of Naples directed by Arnaldo Piutti (1857-1928) and by the Polytechnic of Milan whose Director was Giuseppe Colombo (1836-1921) was reported in the Official Bulletin of the ministry of Public Instruction published after the war, in 1919, by the General Director of the Ministry, first name??? G. Filippi. ${ }^{35}$ The Institute of Naples mainly produced chloropicrin, well-known for its explosive power and its employment as an asphyxiating tear gas. Filippi added:

The connection between the Institute and similar European institutions was remarkable. At an early stage, a French and an English Commission visited the Institute's facilities and brought data and information back for their own use.

[...] Later on, a Japanese Commission directed by General Cikushi visited the Institute, which also received the visits and the praise of British General Foulkes, Head of the asphyxiating service on the French front, of the American Colonel Zanetti, of Commander Osamu Kurowa, and of General-Lieutenant H. Krishineoto of the Japanese Imperial Fleet ([Filippi 1919], p. 345-346).

The role of the Milan Polytechnic and its commitment during the war was remarkable. Colombo was not only a university professor, but also a rich entrepreneurhe had founded the Edison company in Italy - and a politician who had served as

\footnotetext{
${ }^{33}$ For a detailed study of sound-ranging techniques in France and Italy, see [Schiavon 2003a] and [Schiavon 2003b].

${ }^{34} \mathrm{On}$ the polemic and, generally, on Italian and French phonotelemetric measures during WWI, see [Schiavon 2003a], vol. 2, chap. 7 .

${ }^{35} \mathrm{On}$ Colombo and his involvement in politics, science, and industry as director of the Polytechnic of Milan, see [Lacaita 2007].
} 
minister and was a senator of the kingdom of Italy. Before the war, when Volterra as director of SIPS conducted a policy aiming at strengthening the relations between science and industry, a new National-Technical Committee was established in Milan with Colombo at its head. This Committee was a noteworthy exception in Italy, where links between scientific, industrial, and military organizations were on the whole rather weak.

In his report, Filippi devoted two pages to the activity of the Polytechnic during the war. Acknowledging the importance of its contributions to the war effort, Filippi described them in more detail:

During the war the Experimental Laboratory for Building Materials carried out more than 100,000 tests, which had been requested by military authorities and by auxiliary plants; it functioned as the official laboratory of the Milan Division of the Technical Direction of the Air Force; in addition, it worked for the Navy, the Battalion of aerostats, the aeronautic plant in Rome, the Commission for Field Kitchens, the Army Service Corps, and so on. [...] It was able to buy new machinery and new instruments thanks to subsidies from the Aviation Service Corps and the Ministry of War. Its work mainly concerned the testing of all kinds of steel, wood, cement, stone, containers for compressed gases, components of flying machines, projectiles, etc. It also made research for private plants and tested many kinds of testing apparutuses, and contributed to the diffusions of materials quality testing to small factories without suitable tools ([Filippi 1919], p. 355-356).

2.3. The Central Institute of Aeronautics. Another domain where Italian scientists were able to establish close relations with their foreign colleagues from Allied countries was in the rising field of aeronautics, where Italy had an impressive early start. ${ }^{36}$ The first courses of aeronautics to be given in Europe actually took place at the Istituto Centrale Aeronautico (ICA), founded in 1908 by Arturo Crocco (1877-1968) with Volterra's decisive help. ${ }^{37}$ A wind tunnel had already in 1903 been built under Crocco's supervision - together with a British counterpart, it was the first of its kind in Europe.

Despite a promising start, Italy however failed to adopt ambitious plans for pursuing aviation, focusing instead on the development of more efficient dirigibles. A first experimental airship was built in 1906 by Crocco, together with first names??? Ricaldoni and Munari. Two years later the first military dirigible in Italy (the so-called P.1) was produced in plants for aeronautical constructions set up in Rome and in nearby Vigna di Valle employing 128 civilians, 32 tailors, and 326 military workers. Once again, Crocco was in charge of the theoretical supervision of the construction while Ricaldoni oversaw its technical aspects. A hydroplane built by Crocco himself was used as a theoretical basis for the P.1, which was also known

\footnotetext{
${ }^{36}$ An overview on the history of aerodynamics is in [Anderson 1997]: on wind tunnels in particular, see p. 296-299. For another case study of aeronautics research in prewar Europe, see Laurent Rollet and Philippe Nabonnand's contribution to this volume.

${ }^{37}$ The ICA was closely followed by the Paris École nationale supérieure d'aéronautique established in 1909. See [Siegmund-Schultze 2003], p. 71. More about French aerodynamic research at this time may be found in [Fontanon 2003], [Fontanon 2010], [Fontanon forthcoming], and [?].
} 
as the "little dirigible" ("P" stood for piccolo). The Roman plant then put other airships into production, such as the P.2 and the P.3 (used in the military invasion of Tripolitania in 1911), the M.1 (the "medium" one), and then the P.4, P.5, and M.2. The institutional picture was completed by the Aeronautic Observatory set up by Lieutenant Cristoforo Ferrari in Vigna di Valle in 1909, which started to launch sounding balloons three years later. A second - and far superior - wind tunnel was built in 1914 by Crocco. Able to reach velocities as high as $200 \mathrm{~km} / \mathrm{h}$, this wind tunnel functioned until 1935 when Crocco oversaw the establisment of Guidonia which came to be known as the "air town."

In the development of the aeronautical sector, Volterra also played a prominent part not only as an influential political figure, but also as an experimenter. ${ }^{38}$ In 1911 he served on a commission established to improve aerial navigation headed by Lieutenant-General Giuseppe Valleris. ${ }^{39}$ This Commission was active until 1922, with some changes due to the war. Volterra was moreover called to take part in various others committees and commissions set up during the war, such as the Committee for coordination and improvement of the Aerological service.

When war broke out, this entire organization was put to the service of defense. The Volterra Archives holds various technical documents showing that the mathematician was heavily involved in the programs. New airships had to be designed. New firing tables needed to be computed for dirigibles. Volterra traveled trough the country to carry out experiment and test new materials. The war also intensified international cooperation. It seems that Volterra and Crocco wished to enroll British help in the hope of scaling up their dirigible program. Writing from London in April 1916, Crocco reported on the progress of this collaborative program:

Here, they welcome our " $G$ " [the "big" one] in the most flattering way. They have a need for dirigibles [...] and lack the technical expertise for building them.

Therefore, they have the best possible opinion of this project, which, although it has yet to be completed, presents itself as having a firm basis and extraordinary aeronautical efficiency.

However, we shall need to change the objectives we suggested in Italy $[. .$.$] . Here, they do not want offensive, but reconnois-$ sance [airships]. The English mentality, moreover, ignores inertia. Nothing is therefore decided as to whether it will be built, even if everything leads us to believe that it will, and - since they already have all the proper equipment - that it will probably be built in England.

Waiting for these decisions - which are compouned by the English government's difficulties to satisfy Italian requests for machineguns, I do not know for how long I will have to stay here. I therefore think with nostalgia about the whole program in progress there [in

\footnotetext{
${ }^{38}$ See [Volterra 1916]. Concerning Voltera's experimental work for the compilation of firing tables, see Crocco's lecture at the Conference Celebrating the First Centenary of Volterra's Birth [Crocco 1961], p. 26-27.

${ }^{39}$ Italy's Minister of War to Volterra, November, 1911, VA:ADL.
} 
Italy]: I miss the intellectual stimulation I derived from our daily exchanges of ideas $[\ldots] .^{40}$

Meanwhile, Volterra was actively working on setting up a more suitable institutional environment for the pursuit of war-related scientific research back in Italy.

2.4. The Office for Invention and Research. For Volterra, France was the obvious model to organize the scientific mobilization of Italy. But in France, like in Italy, even if some invention evaluation boards preexisted to the war, the mobilization of the scientific resources of the country was at first mostly a matter of personal initiatives. In November 1915, however, the mathematician Paul Painlevé who since August 1914 headed an invention evaluation committee, already mentioned, became minister of Public Instruction, of Fine Arts, and of Inventions Concerning National Defense. Painlevé immediately established a Direction of Inventions [Direction des inventions intéressant la défense nationale] and placed another mathematicians Émile Borel at its head. ${ }^{41}$ Taking inspiration from Britain which had already set up its own Board of Invention and Research (BIR) in July 1915, Painlevé's ambition was to institutionalize, to rationalize, and to strengthen the mobilization of French scientific resources for military purposes.

On 27 December, 1915, Volterra wrote to Borel (who had just lost his adoptive son Fernand Lebeau):

I learned that you were militarized [sic] and that you are now head of the study board of inventions that is part of the Ministry of Public Instruction. I think that you will be very busy with the work of this board which is very important. For several months, I have been part of the Military Aeronautical Institute. I am carrying several experimental and computational tasks over there. We work with great ardor to prepare all that is necessary for this crucial branch of the army. ${ }^{42}$

On 4 January, 1916, Borel replied expressing the wish that official collaboration be established between various Allied boards of invention: "I hope that [...] we

40 "L'accoglienza qui fatta al nostro " $G$ " non poteva essere più lusinghiera. Hanno bisogno di dirigibili (come rileverà dall'accluso articolo) e non hanno alcuna preparazione tecnica per costruirli.

Hanno fatto quindi il miglior viso possibile a un progetto che, sebbene non ancora completo, si presenta tuttavia impostato su basi solide e prevede un rendimento aeronautico eccezionale.

Però occorrerà cambiare lo scopo che noi ci eravamo proposto in Italia, come rileverà dal citato articolo. Qui non vogliono offensiva, ma servizio di esplorazione. Ed inoltre la mentalità inglese non è sprovvista d'inerzia. Nulla è perciò ancora deciso circa la sua costruzione, sebbene tutto lasci supporre che si farà, e, poiché sono già attrezzati, si farà probabilmente in Inghilterra.

Nell'attesa di queste decisioni, complicate dalla difficoltà da parte del governo inglese di soddisfare alle richieste italiane di mitragliatrici, io non so prevedere quanto tempo mi toccherà di rimanere quassù. Penso quindi con nostalgia a tutto il programma che si sta svolgendo costaggiù: sento la mancanza prolungata di quell'appoggio intellettuale che nel nostro scambio giornaliero di idee, guidava la mia mente; e mi oriento, desideroso, verso $i$ collaboratori italiani, e verso Lei, Senatore, con particolare frequenza" (Crocco to Volterra, 2 April 1916, VA:ADL). Is there no secondary literature about this???

${ }^{41} \mathrm{On}$ this see the chapter by David Aubin, Hélène Gispert, and Catherine Goldstein in this book.

${ }^{42}$ Volterra to Borel, 27 December, 1915, VA:ADL; repr. [Mazliak \& Tazzioli 2010], p. 66. 
will achieve the coordination of our efforts, which is the main strength of our enemy and to which the liberal priciples of the great western powers are not without putting barriers" ([Mazliak \& Tazzioli 2010], p. 68). The following October, while emphasizing that scientific relations with Britain were very tight, Borel lamented the fact that relations with Italy were less developed and announced his intention of visiting Italy (Borel to Volterra, 1 October 1916; repr. in [Mazliak \& Tazzioli 2010], p. 95-97). At the end of November, it was Volterra's turn to visit him in Paris.

At the beginning of 1917 , Volterra was finally in position to create a research council in charge of overseeing war-related scientific research at a national level. The following letter (dated 27 February 1917) from the under-secretary of Arms and Munitions to the minister of War - which we quote in full and of which a copy was sent to Volterra - details the tasks of the new body which was clearly organized along the lines adopted by Allied nations and especially the French:

In a personal letter from 2 November of this year [1916], His Excellency the Minister of Public Instruction drew the attention of Your Excellency to the advisability, pointed out to him by Mr. Emilio Borel [sic], Head of Cabinet of the French Ministry of Inventions, to send there an Italian professor who could study the manner in which scientific institutes and university laboratories are associated with the military administration with regards to inventions, and suggested to entrust Senator Professor Volterra with this task.

Acquiescing to this suggestion, Your Excellency assigned this specific task to the said Professor Volterra, who, when his mission was concluded, addressed to Your Excellency a detailed report on the French organization of everything related to national defense, the conclusion of which was that it would be advisable to Italy to mobilize the scientific strength of the country and make use of various scientific institutes' important resources in order to lighten the burden on military technical plants and offices.

Agreeing to this advisability, Your Excellency invited Professor Volterra to design a project expressing the aims and competences of the new Office that would have to be created for this purpose, and indicating the public and private institutes on which the Office might draw for scientific or experimental assistance.

In consequence, Professor Volterra presented to Your Excellency a meticulous project for the new Central Office [...]

Your Excellency having in principle accepted these proposals and agreeing with my suggestion that purely scientific work be clearly distinguished from practical proposals that have the pottential of being immediately implanted, I therefore suggest that a new office for the study of inventions be created on the basis of the present Department of Inventions of the under-secratary [of Arms and Munitions]. This Office would receive the task of communicating to the specialized offices placed under the authority of the under-secretary all inventions that are strictly military in character or that directly concern artillery, engineering, or aeronautical materials, merely keeping a statistical trace of them, while it would 
communicate directly with the various non-military scientific institutes all matters that concern the analysis and technical evaluation of all other inventions that are susceptible of contributing to national defense.

While supremely usefulness in all respects, such a criterion for the sharp distinction between competences is a quasi-obvious necessity that needs no further illustrative elaboration.

And since Professor Volterra has already had the occasion of observing the French organization of such matters at first hand, I should suggest, if Your Excellency agrees with what was said above, that Professor Volterra - who better than anybody else could live up to the important task which would thus be entrusted to himbe called upon to head the Office to be created. ${ }^{43}$

The papers left by Volterra show that his involvement in the organization of UIR thus created was intense. These documents allow us to reconstruct the way in which the new institution was created, its purpose, the difficulties it faced and the way it was abolished. Let us quote at length from a memorandum Volterra addressed, as head of UIR, to the under-secretary for Arms and Munitions (date???):

43"Sua Eccellenza il Ministro della Pubblica Istruzione con lettera personale del 2 Novembre u.s. [1916] faceva presente all'E.V. l'opportunità, fattagli rilevare dal Sig. Emilio Borel Capo di Gabinetto del Ministro delle Invenzioni in Francia, di inviare colà un Professore Italiano per prendere conoscenza dei rapporti esistenti fra gli Istituti Scientifici e i Laboratori Universitari con le Amministrazioni Militari in materia di Invenzioni; e proponeva di affidare tale incarico al Senatore Prof. Volterra.

V.E. in adesione a tale proposta, affidava l'incarico specifico al detto Prof. Volterra, il quale, compiuta la sua missione, indirizzava a V.E. stessa una dettagliata relazione sulla organizzazione francese per tutto ciò che riguarda le invenzioni interessanti la difesa Nazionale, concludendo con l'opportunità di mobilitare anche in Italia le forze scientifiche del Paese e di utilizzare le risorse non trascurabili dei numerosi Istituti Scientifici, e ciò con sollievo degli Stabilimenti ed Uffici Tecnici Militari.

Convenendo su tale opportunità V.E. invitava il Prof. Volterra a formulare un progetto in cui fossero meglio precisati gli scopi e le attribuzioni del nuovo Ufficio che si sarebbe a tal fine dovuto costituire, e dal quale fosse risultato di quali Istituti Pubblici e privati ci si sarebbe potuti avvalere pel concorso scientifico o di indole sperimentale.

Il Prof. Volterra di conseguenza presentava a V.E. un progetto organico del nuovo Ufficio Centrale da istituire [...]

V.E. avendo in massima accettato siffatte proposte e convenendo a mio avviso tener presente ciò che è lavoro scientifico da ciò che è proposta pratica e quindi di immediata attuazione, se adatta allo scopo, proporrei costituire un nuovo ufficio per lo esame delle proposte di invenzioni, il quale potrebbe trarre il suo nucleo costitutivo dall'attuale Reparto Invenzioni di questo Sottosegretariato, e che dovrebbe avere il compito di trasmettere senz'altro ai diversi uffici speciali del Sottosegretariato stesso quelle invenzioni di stretto carattere militare o concernenti materiali di Artiglieria, Genio, e Aeronautica sì da conservarne presso di sé la sola traccia statistica, mentre dovrebbe mettersi in diretta relazione coi vari Istituti Scientifici Civili per quanto riguardi lo studio e l'esame tecnico di tutte le altre invenzioni che interessano la difesa del Paese.

Tale criterio di netta separazione di attribuzioni è di una necessità così ovvia da non richiedere alcun cenno illustrativo, mentre riuscirebbe sotto ogni riguardo della massima utilità.

E poiché il Prof. Volterra ha già avuto occasione di vedere da vicino l'organizzazione data in Francia a tale materia, proporrei, nel caso V.E. accedesse a quanto sopra è detto, che fosse chiamato a dirigere il costituendo Ufficio lo stesso Prof. Volterra, il quale meglio di ogni altro potrebbe rispondere all'importante compito che gli verrebbe in tal modo affidato" (VA:ADL, Cartella VI). 
The task of this Office, which was established with the purpose of collecting and examining inventions concerning national defense, has very adequately been expanded so as to encompass interesting scientific and technical issues relevent to the same class of problems. This second task [...] is rather wide, since modern warfare is more or less directly using all of the country's industrial resources and requires that the performance of each resource be driven to the maximum. The problems that must be resolved if this aim is to be attained can be group in the following three categories:

(1) Problems of purely industrial and technical character [...].

(2) Problems suggested by practical application, but that bear on questions of scientific interest, and which it is therefore adequate to study from a general or comprehensive point of view. From their solution, mostly derives an extension of scientific conquests beneficial to technical practice, from which other applications may spring, more or less associated with the one from which the problem arose originally.

(3) Problems of scientific character, whose elements belong to the field of pure research and that ought to be studied independently from practical applications that may derive from them. [...] Problems belonging to the third category can conveniently be studied in university laboratories; those belonging to the second [category] in laboratories equiped with workshops and administered by the state; and those belonging to the first [category] in industrial settings. In general, the study of these problems asks for experiments. What is therefore needed is the following:

(a) to have experienced staff for conducting experimental research relative to various subject-matters;

(b) to have conveniently equipped laboratories at one's disposal;

(c) to possess adequate financial means. ${ }^{44}$

\footnotetext{
44 "Il compito di questo Ufficio, sorto con lo scopo di raccogliere ed esaminare le invenzioni relative a problemi interessanti la difesa nazionale, si è molto opportunamente allargato associandovi quello delle ricerche di carattere scientifico e tecnico interessanti la stessa categoria di problemi. Questo secondo compito, ora indicato anche nel nome dell'Ufficio, è assai vasto, perché la guerra moderna, utilizzando più o meno direttamente tutte le risorse industriali del Paese, esige che il rendimento di ciascuna sia spinto al massimo grado.

I problemi da risolvere per il raggiungimento di questo fine possono essere catalogati secondo i tre tipi seguenti:

(1) Problemi di carattere puramente tecnico-industriale. Per studiarli si deve scegliere il metodo che più direttamente possa condurre al risultato pratico, ed ogni ricerca relativa, principale o sussidiaria, è limitata al campo dell'applicazione pratica, che si ha in vista.

(2) Problemi, il cui enunciato è suggerito dalla previsione di una pratica applicazione, ma che hanno attinenza con questioni di interesse scientifico, ed è quindi opportuno di studiare da un punto di vista generale e comprensivo. Dalla loro risoluzione col vantaggio della tecnica si associa per lo più un'estensione dalle conquiste scientifiche, da cui altre applicazioni possono germogliare più o meno connesse con quella da cui il problema ha tratto origine.

(3) Problemi di carattere scientifico, i cui argomenti appartengono al campo della ricerca pura, e che debbono essere studiati indipendentemente dalle applicazioni pratiche che possono derivarne $[\ldots]$
} 
As soon as it was estabished, UIR changed rapidely and was increasingly turned into a body for scientific consultancy. Already divided in various sectors (the Mathematical, Physical, Chemical, Electrical Branches...), UIR also set up several special technical commissions focusing on nitrogen, zinc, potassium, helium, etc. As Volterra explained to the under-secretary in an undated letter, these commissions were modelled on those existing in other countries and were useful for quickly getting a specialist's opinion when needed (VA:ADL, Cartella VI).

To develop his project and increase the scientific competitiveness of UIR, Volterra required adequate funding. With this goal in mind, he wrote the under-secretary on 18 June, 1918, to explain the structure of UIR:

The Office for Invention and Research was created for the modest task of evaluating inventors' proposals, but (following the example set by similar institutes created by other warring countries) it became a body for scientific and industrial consultancy that all ministries, and the ones concerned with military affairs especially, trust with the assessment of technical and practical questions, the pursuit of scientific research, and the conception of new industries relevent to the country's defense and economy.

The Office thus essentially consists of two divisions: Inventions, assigned to a special group of technicians; and Research, assigned on case-by-case basis to special commissions appointed with welldefined aims.

The Office belongs to the ministry of Arms and Munitions and is placed directly under the authority of the under-secretary, according to what was decided when it was created and confirmed to me by Your Excellency when I paid him a visit yesterday.

However, the Office has established relations with various other ministries, in particular with the ministry of Naval Affairs (through a section directed by Admiral Avallone and by General Valsecchi from the Naval Engineers Corps) as well as with the analogous offices of the Allied nations. It therefore has representatives in Paris, London, and Washington, while the English government has a representative at the Office, and France and the United States will be represented soon.

As said, the [business of the] Division of Research is assigned to commissions specially appointed for the purpose at hand whenever the ministry of Arms and Munitions, whether from an initiative of its own or after agreement with other ministries, request some particular theoretical or practical investigation from the Office.

Several of these Commissions have already completed their task and sumitted recommandations that have been translated into

I problemi della terza categoria si studiano convenientemente presso i Gabinetti Universitari; quelli della seconda presso i Laboratori forniti di officine dipendenti dalle Amministrazioni dello Stato; quelli della prima presso gli Stabilimenti Industriali. Lo studio di questi problemi esige in generale l'esperimento. '̇ pertanto necessario: menti;

(a) avere il personale esperto nella condotta di ricerche sperimentali attinenti ai vari argo-

(b) disporre di Laboratori convenientemente attrezzati;

(c) di possedere mezzi finanziari adeguati" (VA:ADL, Cartella VI). 
ministerial decisions. Let me recall the work done by the Commission for Raw Materials regarding the production of sulphuric acid whose recommandations were implemented through agreement between the ministry of Arms and Munitions and the ministry of Agriculture; let me also mention the work of the Commission for Bomb Welding which, [...] through its practical studies and instructions, favored the development of electric welding and put together an exhibition in Milan to convince manufacturers of the advantages of the new system. ${ }^{45}$

A few months after this letter was witten, the Allied nations had won the war and UIR was dissolved. But this experience was not lost on Volterra who endeavored to establish a new institution with the aim of perpetuating the collaboration of pure and applied scientists amon themselves and with the military and industry. This was an institution that postwar Italy needed to reemerge on more solid bases and with a stronger national industry. In this sense, wartime UIR sowed the seed of the CNR with which we shall deal in section 3.2 .

2.5. The Sixth Army. "[N]ot only is mathematics beautiful, it may also be useful" ([Picone 1972], p. 7). This is what in his autobiography an old mathematician remembered thinking when as a young man he was mobilized on the Trentino front and was quickly able to solve a pressing ballistic problem assigned to him by

45 "Facendo seguito a quanto ebbi l'onore di riferire alla E. V. ritengo opportuno di esporre quale sia nelle sue linee generali la costituzione dell'Ufficio Invenzioni e Ricerche, quali le relazioni gerarchiche interne ed esterne, quali infine le Commissioni di ricerca dipendente dall'Ufficio ed $i$ compiti alle medesime affidati.

L'Ufficio Invenzioni e Ricerche nacque col modesto compito di esaminare le proposte presentate dagli inventori, ma questo (seguendo l'esempio dei consimili Istituti creati dalle altre nazioni belligeranti) divenne un organo di consulenza scientifica ed industriale a cui tutti $i$ Ministeri, ed a modo speciale quelli militari affidano l'esame di questioni tecniche e pratiche, l'esecuzione di ricerche scientifiche, l'approntamento di progetti di nuove industrie interessanti la difesa e la economia del paese.

Esso è quindi essenzialmente diviso in due servizi, quello delle Invenzioni affidato ad uno speciale corpo di Tecnici e quello delle Ricerche che viene affidato caso per caso a speciali Commissioni nominate con scopi ben determinati.

L'Ufficio fa parte del Ministero Armi e Munizioni e dipende direttamente dal Sottosegretario, secondo quanto fu stabilito dalla sua costituzione e mi è stato confermato dalla E. $V$. in occasione della mia visita di ieri.

L'Ufficio ha però relazioni coi vari altri Ministeri e specialmente con quello della Marina (a mezzo di apposita Sezione diretta dall'Ammiraglio Avallone e dal Generale Valsecchi del Genio Navale) nonché cogli Uffici analoghi delle Nazioni alleate. Ha perciò suoi rappresentanti a Parigi, a Londra, a Washington, mentre presso l'Ufficio è rappresentato il Governo Inglese e saran presto rappresentati quelli di Francia e degli Stati Uniti.

Il Servizio Ricerche è affidato, come già dissi, a speciali Commissioni, che vengono appositamente costituite ogni qualvolta il Ministero delle Armi e Munizioni o per sua iniziativa o per accordo con altri Ministeri decide di affidare all'Ufficio una speciale indagine teorica o pratica.

Varie di queste Commissioni hanno già espletato l'opera loro, presentate da proposte che furono tradotte in provvedimenti ministeriali. Ricorderò l'opera della Commissione per le materie prime occorrenti alla produzione dell'acido solforico, che propose i provvedimenti tradotti poi in pratica d'accordo tra i Ministeri delle Armi e Munizioni e dell'Agricoltura; cosi pure ricorderò l'opera della Commissione per la saldatura delle bombe che ha studiato profondamente tale problema in vista specialmente della saldatura delle bombe ed ha favorito lo sviluppo della saldatura elettrica con studi e con indicazioni pratiche, indicando in Milano apposita esposizione per convincere gli industriali della convenienza del nuovo sistema" (VA:ADL, Cartella VI). 
his superior. A recent graduate from the Scuola normale superiore of Pisa, Mauro Picone was 25 years younger than Volterra. His experience of WWI was therefore very different from that of the overseer of the Italian scientific mobilization, but it arguably had a stronger influence on his future life and career.

Before the outbreak of WWI, Picone, who has studied with Luigi Bianchi (18561928) and Ulisse Dini (1845-1918) among others, was a young promising mathematician. He could already count numerous significant publications contributing to the theory of ordinary and partial differential equations. Remaining in Pisa as Dini's assistant untill 1913, he then accepted an assistant position in rational mechanics and analysis at the Turin Polytechnical School. ${ }^{46}$

The portion of the front Picone was sent to, in the Trentino, was a mountainous area. He served under Colonel Federico Baistrocchi who would later play a prominent political role in the Fascist regime. At the time, Baistrocchi was however facing serious trouble with his artillery. Medium- and large-caliber artillery was made useless in this mountainous zone, due to failings in Siacci's old firing tables. Even if summarily corrected, the tables derived from his classical treatise on ballistics [Siacci 1888] produced catastrophic results. In Picone's account, Baistrocchi asked for the young mathematician's help as soon as he heard he had joined his unit. He specifically requested new firing data in order to help destroy enemy strongholds. And, after about one month of intense computing, Picone successfully concluded his task. "After this success, one can imagine how I came to see mathematics differently" ([Picone 1972], p. 7).

Picone drafted a note "On the Firing of Medium- and High-Caliber [Cannons] in the Mountain" [Picone1917] which explained his achievement. His contribution to the war effort is best summarized in a report probably written by the mathematician Guido Fubini (1879-1943) then a professor at the university of Turin. Recounting the story of Picone's encounter with Baistrocchi, the report describes the technical problem artillerymen faced with Siacci's old firing tables. It states the assignment given to Picone:

Find the inclination of the artillery piece such that the smallest possible charge will be needed to reach the target, overcome resistance, and activate the fuse. Determine the inclination and the load; compute the adequate changes to be given either to the load or the initial angle to adjust for the varying $y$-coordinate of the point of impact, for instance by $100 \mathrm{~m}$ [eter].

By using the firing tables computed by Picone, this problem could always and easily be solved in the field, even by people ignorant of ballistics. ${ }^{47}$

\footnotetext{
${ }^{46}$ After the war, Picone taught successively at the universities of Cagliari, Catania, Pisa, and Naples, where he remained from 1925 to 1932, when he moved to his definitive chair in Rome.

47 "Determinare quell'inclinazione da dare al pezzo, per la quale la carica occorrente a portare il proietto sul segno, a superare gli ostacoli frapposti e a far funzionare la spoletta, sia la minima possibile. Determinare l'inclinazione e la carica, calcolare, per l'aggiustamento del tiro, la variazione da far subire o al peso della carica o all'inclinazione del pezzo, per far variare, alla costante quota del bersaglio, l'ascissa del punto d'arrivo del proietto, ad esempio di m. 100.

Colle tavole di tiro che dovrebbe costruire il Picone questo problema potrebbe prontamente essere sempre risoluto in batteria, anche da chi ignorasse la Balistica" (Report annexed to a letter from Segre to Volterra, 13 January 1917, VA:ADL.).
} 
To achieve his end, Picone created a small computational bureau in a ramshackle wooden barrack in the Dolomites. But in this makeshift installation, one can see the root of the Institute for the Application of Computing (IAC) which Picone was later able to establish with the support of CNR. ${ }^{48} \mathrm{He}$ once remembered how towards the end of 1916, a chance encounter with Volterra had made a strong impression on him and reinforced his conviction that such an institution could render great services to science and industry. Waiting to be received by his superior officer, Captain Volterra shared some thoughts about the war and about tactical and technical problems with his young colleague who remembered them forty years later in the obituary he wrote for Volterra ([Picone 1956], p. 3285). Volterra, Picone recalled, spoke of the necessity of a closer collaboration between science and technology, which would not only immediately increase the Italian Army's military capacities but also be instrumental to the industrial and sanitary progress of Italy in peacetime. Picone went on:

Thus did I find a first - authoritative and extremely encouragingsupport for the idea which had come to me when I faced the problems that plagued our heavy artillery between our Alps' lofty peaks and abyssal valleys - the idea of an Institute for the Application of Computing (which I was able to establish some ten years later at the university of Naples) designed to mobilize the powerful instruments of numerical computing for the quantitative mathematical analysis of the problems of experimental science and of technology ([Picone 1956], p. 3285).

In the following passages excerpted from a commemoration in honor of Antonio Signorini, Picone shared some vivid recollections of the war experience that had led to this idea:

[Signorini] also devoted himself to ballistics. He did so, intensely in the years 1917-1922, driven at first by the needs of our artillery as they arose during the war of 1915-18, and later, in 1946, by his position as a consultant for [IAC] which I then directed. He dealt with both external and internal ballistics, which he studied after the defeat of Caporetto, from 1917 to 1918, at the Artillery Headquarter of the Sixth Army [which was] operating in the Asiago Plateau. He was called there, on my proposal, to join a group of officers who were on the ground so as to be able to step in immediately and usefully whenever the solution of frequent and unexpected problems of a mathematical nature was needed for the tactical use of our medium- and large-caliber artillery. This group consisted of il Nostro [Signorini], the mathematicians Alessandro Terracini, Domenico Mattioli, Gino Cecchini, Arturo Cecconi, the engineer Brusini (a brave refugee from Trieste whose first name I unfortunately do not remember) and the undersigned, and I cannot refrain from adding that it was this group's useful work in the application of mathematics to the solution of the problems of field artillery that gave rise to the idea for the foundation of [IAC] in

${ }^{48}$ We analyse the consequences and the development of these ideas below in section 3.3. 
1927 as part of my chair of infinitesimal calculus at the university of Naples.

Artillerymen in charge of medium- and large-caliber pieces were complaining about the loss of initial velocity [...] due to the wear and tear of the pieces, which caused the projectiles, when inserted into the bore, not to sink as much as in unused ones; as a consequence the combustion chamber increased in volume considerably. Well, [Signorini] was able to compute the loss incured by the initial velocity imparted to the projectile at the blast of the explosive in the enlarged chamber, in function of the (easily measurable) advance of the projectile in the bore; this loss being known, standard formulae of external ballistics could be applied to determine the angle correction affecting the inclination of the piece in order for the staff to be able to use the firing tables that were at their disposal to reach their target. After the war, [Signorini] published a thermodynamical, analytical, and numerical study of this problem in a paper entitled "Calcolo della perdita di velocità iniziale dovuta al logorio dell'anima", in vol. IV from 1919 of the Rivista d'Artiglieria e Genio. It should be noted that this beautiful article presents a new method for the approximate determination of one-dimensional integrals which has a remarkable approximating efficiency and which, in modern numerical analysis, is known as "Signorini's method." 49

In an unpublished typeritten report dated "Catania, December, 1919," Picone further described the way in which his methods were implemented in the Sixth Army: $:^{50}$

In February 1918 artillery command of the Sixth Army was taken over by General Roberto Segre, one of the most learned and most brilliant artillery officers of our army.

General Segre was one of the most vigorous supporters of my firing methods [...]. He wanted without delay that every calibers [that is, all models of cannons] in our artillery be given rational firing tables calculated on the scientific basis I had laid down.

He provided me with all the means I requested. At the Army's headquarter, an office for ballistic studies was set up, which was later known to have an analogue in Paris, at the Artillery Depot of the French Army. Eminent mathematicians like Borel, Hadamard, Lebesgue, and Montel worked in this Paris office.

In our small office, located in the attic of a countryside farm, I worked together with the collaborators I was able to assemble: Professor Terracini (Lieutenant of the Engineers), Dr. Cecconi (Artillery Lieutenant), Engineer Brusini (Artillery Lieutenant), Dr. Mattioli (Second Lieutenant of the Infantry), and later, toward the end of October 1918, Professor Signorini (Artillery Lieutenant),

\footnotetext{
${ }^{49}$ [Picone 1964], p. 397. See also [Signorini 1919] and [Signorini 1922].

${ }^{50}$ Presented to the Competition of Analysis for the University of Cagliari, this report is kept in the Archivio Storico dell'Istituto per le Applicazioni del Calcolo "Mauro Picone." We thank its director, Michiel Bertsch, for providing us with a copy of the document.
} 
whom I managed to take out of a position where he could not achieve anything. We had five calculating machines, [human] computers, draughtsmen.

The office worked day and night. Due to this, I list among my work the publications of the artillery headquarter of the Sixth Army [...]. The artillery of the Sixth Army and of some of the neighbouring Armies were thus provided with all the technical firing advances that had been achieved by the Allies, sometimes achieving progress that, in many respect, could stand the comparison with the methods used by the Allies. ${ }^{51}$

In this official report, Picone described an efficient team working with the support of the Italian army and developing methods able favorably to compete with those of other Allied nations. ${ }^{52}$ Things were however somewhat messier. In the letter Segre wrote to Volterra on 13 January 1917 to which was appended a report we have already quoted and assigned to Fubini, the difficulties Picone encountered at a military and a practical level come to the fore:

In consequence of the excellent results deriving from Picone's computations in campaigns at the Alpe of Cosmagnon and the pick of Pasubio last summer, Dr. Picone [...] was asked to compute here, during the winter, new tables for the firing of medium- and largecalibre [cannons] in the mountain and given access to the resources of the nearby shooting range of Cirié. This assignment was made as official as possible: Headquarters, ministry of War, and so on. And the work is supposed to be completed by the end of March.

Well, at the shooting range of Cirié, after [receiving] many compliments, Picone (1) was informed that he had to wait for the appropriate ministerial authorization before firing any shot that

\footnotetext{
51 "Col febbraio 1918 assunse il Comando dell'Artiglieria della VIa Armata il Generale Roberto Segre, uno dei più colti e più brillanti ufficiali d'artiglieria del nostro esercito.

Il generale Segre fu uno dei più fervidi fautori dei miei metodi di tiro (leggere le circolari sue, riportate nel Fascicolo I A - Titolo n, 24 - e nel Fascicolo I B - pubblicazione n. 22 - delle Tavole di Tiro di montagna). Egli volle che si procedesse senza indugio a dotare ogni calibro della nostra artiglieria di razionali tavole di tiro compilate sulle nuove basi scientifiche che io avevo posto.

Egli mi forni di tutti $i$ mezzi che io richiedevo. Al Comando dell'Armata si istitui un vero e proprio ufficio di studii di Balistica, che si seppe poi avere un analogo a Parigi, presso il Deposito d'Artiglieria dell'esercito francese. In questo ufficio di Parigi lavoravano insigni matematici, come il Borel, l'Hadamard, il Lebesgue, il Montel.

Nel nostro ufficietto, sito in una soffitta di una fattoria di campagna, lavoravamo io e $i$ collaboratori che avevo potuto ottenere: il Prof. Tarracini (Tenente del Genio), il Dott. Cecconi (Tenente d'Artiglieria), l'Ing. Brusini (Tenente d'Artiglieria), il Dott. Mattioli (S. Tenente di Fanteria), e, più tardi, verso la fine di ottobre del 1918, il Prof. Signorini (Tenente d'Artiglieria), che riuscii a strappare da una situazione, nella quale egli non poteva rendere nulla. Ebbi cinque macchine calcolatrici, calcolatori, disegnatori.

Il lavoro era diurno e notturno in questo ufficio. A questo lavoro si devono le pubblicazioni del Comando d'Artiglieria della VIa Armata elencate fra i miei titoli [...]. All'Artiglieria della VIa Armata e a parte delle Armate limitrofe, si fornirono cosi tutti i perfezionamenti tecnici del tiro che erano stati conseguiti presso gli alleati, realizzando anche, in molti punti, progressi notevolissimi, di fronte ai metodi in uso presso gli alleati."

${ }^{52}$ For an extensive bibliography on external ballistics, see [D'Adhémar 1934].
} 
might be needed for his experiments and to check his computations; (2) was also forbidden to examine results of any prior experiments [performed on the site] without a new agreement with the Ministry; (3) was not even allowed to consult books, without General Arlorio's indirect intervention from Turin. And I'm not even speaking about the fact that no draftsman and no computer was assigned to him!

Fubini himself took care of Picone's problems and also suggested some changes to his method. Among other things he found a formula for adjusting fire which is in general valid and may be used to replace usual correction coefficients which are invalid when the difference in height [between site of fire and target] is too large. [... Colonel Bianchi from [Turin] (the professor of ballistics on whom everything concerning artillery seems to depend...) objected that [Fubini's formula] was too complicated. ${ }^{53}[\ldots]$

Obstructionism in Cirié, obstructionism in Turin with Colonel Bianchi. They do not want any help from those who can deliver it! And this is our Italy [whose fate is at stake]!

Neither Picone nor Fubini have asked me to write you. I alone resolved to do it. May you act to improve the state of things! ${ }^{54}$

What can we conclude from this fascinating sample of published and unpublished material? How can contradictory documents be assessed? More research would be required to provide a more complete understanding of the war work of Italian mathematicians, but the documents here exhibited are enough to hint at the reasons why his wartime experience had a much stronger impact on Picone than any other mathematician involved, like he was, in war research. Fubini and

\footnotetext{
${ }^{53}$ Artillery Colonel Giovanni Bianchi (1861-1917) was indeed an expert in external ballistics. See [Bianchi 1922].

54 "Il Dr Picone, come leggerai in un foglio che qui ti unisco, in seguito agli ottimi risultati che $i$ suoi calcoli avevano dato l'estate scorsa nelle azioni contro l'Alpe di Cosmagnon e contro il Dente del Pasubio, ebbe l'incarico di compilare, qui, nell'inverno, nuove tavole di tiro per il tiro in montagna di medii e dei grossi calibri, valendosi dei mezzi che si trovano nel vicino poligono di esperienze d'artiglieria di Cirié. Questo incarico è dato con tutte le formalità possibili: Comando supremo, Ministero della Guerra, ecc. E il lavoro deve essere ultimato entro la fine di marzo.

Orbene al poligono di Cirié, dopo molti complimenti, il Picone: (1) fu avvertito che per le esperienze di rettifica e di controllo dei calcoli avrebbe dovuto, per ogni colpo, attendere di avere un'apposita autorizzazione ministeriale. (2) ebbe persino il divieto di consultare le vecchie esperienze, senza una nuova corrispondenza col Ministero. (3) nemmeno libri poté avere, se non quando ricorse all'intervento indiretto, a Torino, del generale Arlorio. Non parlo poi del fatto che non gli si diede nemmeno un disegnatore o un calcolatore!

Fubini s'interessò ai problemi del Picone, e gl'indicò anche qualche modificazione nel metodo. Trovò, fra l'altro, una formola per l'aggiustamento dei tiri, valida in generale, da sostituire ai soliti coefficienti di correzione non validi nei tiri con forti dislivelli [...] Il colonnello Bianchi di qui (prof. di Balistica, da cui pare dipenda tutto ciò che riguarda l'Artiglieria ...) gli obbiettò che era troppo complicata [...]

Ostruzionismo a Cirié, ostruzionismo a Torino col colonnello Bianchi. Non vogliono aiuti da chi potrebbe darli! E si tratta della nostra Italia!

Non sono né Picone, né Fubini che mi han detto di scriverti. Sono io solo che ho pensato di farlo. Chi sa che tu non possa agire perché le cose procedano meglio!" (Segre to Volterra, 13 January 1917, VA:UDL).
} 
Severi, Oscar Chisini (1889-1967) and Pietro Teofilato (1879-1952) had war experiences that do not differ much from Picone's. They solved a variety of ballistic and telemetric problems, called forth by the rapid development of artillery and by the need of adapting firing tables to the special geographical conditions encountered in certain phases of WWI. ${ }^{55}$ But after the war they all went back to pure mathematics.

Picone, in contrast, recalled his work for the Sixth Army as a life changing experience. As we have seen, he concluded from this that mathematics was "not only beautiful" but "also useful." This was a hard-won conviction that was forged during decisive years for the determination of his carreer path and scientific character. To be truly useful, moreover, mathematics required to be backed up by the proper organization of research resources. For Picone, therefore, the realization that mathematics may be useful would not lead to the bracketing of his wartime experience. On the contrary, Picone would pursue, even as a civilian, the military experience of appropriating the right resources to make mathematics useful. As we shall see, the establishment of IAC was the concrete expression of an intuition born in the bunkers of WWI.

\section{Some Effects of WWI on the Italian Mathematics Community}

3.1. Italian Mathematicians and Ostracism. After the Armistice, mathematics was engulfed by the seaside transformation in international relations among European states. Generational issues left a deep mark on the mathematical communities that had suffered the most from casualties in the trenches. In France, in particular, the new Bourbaki generation argued that they were called to fill in the void left by those fallen for the motherland. ${ }^{56}$ In Italy, new national schools were established sometimes with a strong and aggressive agenda, especially under the Facsist regime. But in fact, very few Italian mathematicians had died during WWI and most influential mathematicians before 1914 still played a prominent role in the postwar reconstruction.

Institutions and people were physically and moraly wounded by the terrible experience they had just lived through. The happy dream of turn-of-the-century modernity was shattered. People now feared the lapse back to barbarism through the subversion of consolidated powers and customs. Before the war they had dreamed of universal progress made possible by scientific discoveries; now they were awaking to a new reality where there were heated discussions about whether scientific meetings and cooperation with defeated countries would be allowed to take place as if nothing had happened. This was a hard blow to internationalism, which had characterized generations of Italian mathematicians after unification.

It is well known that scientists from Allied nations decided to institute new kinds of international cooperation embodied by the International Research Coucil (IRC), and the International Mathematical Union (IMU), from which German, Austrian and Turkish colleagues were excluded. The first International Congress of Mathematicians to take place after the war was held in 1920 in the symbolic

\footnotetext{
${ }^{55}$ On telemetric problems, see the papers [Chisini 1918] and [Teofilato 1920].

${ }^{56}$ The Bournaki generation had often argued this; see, esp., [Dieudonné 1978]. As is discussed in the introduction of this volume and in the chapter by David Aubin, Hélène Gispert, and Catherine Goldstein, recent historiography is more circumspect about this claim; see also [Leloup 2009], [Beaulieu 2009], [Goldstein 2009], and [Aubin forthcoming b].
} 
location of Strasbourg, a town that France had just recovered from Germany. ${ }^{57}$ In a letter to Volterra, Picard explained the criteria that should be applied for inviting mathematicians to the Strasbourg Congress: "Invitations - addressed to scholars from Allied and neutral nations - will be personal. We do not intend to invite anyone among the neutrals who was too openly against our cause during the war." 58 Volterra was in complete agreement with the hard line. "It is with a very great pleasure that I have seen the choice of this town [Strasbourg] as the seat of the next Congress of Mathematicians." 59 In a letter to Borel, Volterra added: "German militarism has not been knocked down at all; given the occasion it will always try to reassert itself. [...] I have no confidence in what they still want to do." 60

While most French mathematicians seemed adamant about it, Italian mathematicians were more divided about the measure of exclusion than Volterra's militant attitude would seem to indicate. Contrary to what Volterra claimed in many of his letters to Picard, Borel, and Hadamard, Italy was not unanimously against Germany before, during, and after the war. The Mathematical Circle of Palermo, for one, had a different point of view. In a letter to Corrado Segre from 7 October, 1919, its director Michele De Franchis (1875-1946) asserted that "the Circolo does not and will not distinguish mathematicians according to nationality or race" (quoted in [Brigaglia \& Masotto 1982], p. 377). De Franchis never expelled German members from the Circolo and refused to accept Max Noether's resignation. ${ }^{61}$

An ardent believer in the internationalism of science, as we have seen, LeviCivita also opposed any kind of ostracism. In the interwar period, he devoted much effort to the organization of the International Congresses of Applied Mechanics in collaboration with Theodore von Kármán (1881-1963), the director of the Aerodynamic Institute in Aachen. In a letter he sent to Levi-Civita on 2 April, 1922, von Kármán explained that his intention was to to organize a European scientific meeting on fluid mechanics. ${ }^{62}$ In spite of its great interest from a theoretical point of view and of its even greater importance from of a technological one, this domain which attracted mathematicians, physicists, and engineers was not constituted as a single research area. In order to overcome political problems arising from conflicting nationalistic beliefs, von Kármán suggested that the meeting be organized in a rather informal way - he would directly contact his colleagues from Germany, Austria, and formerly neutral countries (including his mentor Ludwig Prandtl and Carl Oseen from Sweden), while Levi-Civita would invite "Romanic and English" scientists. Levi-Civita's choice as a partner was based on scientific and personal grounds: indeed interested both in pure mathematics and in its applications to

\footnotetext{
${ }^{57}$ The next Congress took place in Toronto in 1924. Only in 1928 in Bologna would German mathematicians be welcome to the Congress. On the International Congresses of Mathematicians, see [Lehto 1998] and [Albers et al. 1986]; on the international scientific community in the twenties see [Schroeder-Gudehus 1978].

${ }^{58}$ Picard to Volterra, 28 February, 1920, VA:UDL; repr. [Mazliak \& Tazzioli 2010], p. 139.

${ }^{59}$ Volterra to Picard, March 1920, VA:UDL; repr. [Mazliak \& Tazzioli 2010], p. 141.

${ }^{60}$ Volterra to Borel, April 1920, VA:ADL; repr. [Mazliak \& Tazzioli 2010], p. 142.

${ }^{61} \mathrm{~A}$ bit more about this episode might be nice (at least in a footnote): why did Noether want to resign ? What did he say, if we know? What was De Franchis' answer???

${ }^{62}$ The letters to Levi-Civita are found in Levi-Civita's Archive, Accademia dei Lincei, Rome, hereafter LVA:UDL.
} 
physics and engineering, Levi-Civita was moreover highly esteemed as one of the best Italian mathematicians and as an unwavering internationalist. Levi-Civita enthusiastically accepted von Kármán's invitation, suggesting that the Congress be considered as the "personal business of some scholars," very few in number but excellent in quality. ${ }^{63}$ He invited his colleagues who were specialist in fluid mechanics, including Volterra and Gaudenzio Fantoli (1867-1940), a professor of hydraulics at Milan's Polytechnic. As they were both members of the Italian Committee of the IRC whose statutes excluded the former Central Empires, they expressed strong opinions against any kind of international congress of that sort.

But such negative answers were not enough to cancel the congress. In September 1922, as planned, some thirty scientists met in Innsbruck. Most came from Germany and Austria, but among the former Allies Italy was the only country to be represented. All Italian scientists present, Modesto Panetti, Giulio De Marchi, Bruto Caldonazzo and Umberto Cisotti, were Levi-Civita's friends and pupils. In Innsbruck, other International Congresses were planned on general subjects of applied mechanics - and not only fluid dynamics. The series of International Congresses of Applied Mechanics was launched. The next one took place in Delft on April 1924 and was organized by Jan Burgers (1895-1981) and Cornelius Benjamin Biezeno (1888-1975). ${ }^{64}$

Between Volterra's and Levi-Civita's extreme attitudes, a continuous spectrum of opinions existed. Some wished to renew old ties established with German colleagues before the war. One of them was Luigi Bianchi, who had been Volterra's teacher at the university of Pisa. While he was at the university of Munich from 1979 to 1881, Bianchi had befriended Adolf Hurwitz (1859-1919). In a letter to Bianchi written on 23 January 1883, Hurwitz had even called those Munich years: "the best time in my life." ${ }^{65}$ When WWI broke out Bianchi however expressed very different feelings:

About the Germans, my thought is always the same-indeed, if possible, I hate them more than before, due to the misdeeds that have gethered during this horrible war. It is my firm hope, and also my conviction, that they will eventually have to pay them back dearly. ${ }^{66}$

But in spite of the hate for the Germans he expressed in 1915, Bianchi was soon ready to rehabilitate German scholars in the name of his love of science. Just before the Strasbourg Congress of 1920, Bianchi wrote to Volterra:

You know how much I dislike the German people who have turned the world in such a nice way that old men like me will never be allowed to know better times! But I do believe that, in the very interest of science, it is preferable (if possible) to mitigate hostilities and not to ostracize the scientific production. Now and for many

\footnotetext{
${ }^{63}$ Levi-Civita to von Kármán, 21 April, 1922, LVA:ADL.

${ }^{64}$ On the International Congresses of Applied Mechanics, see [Battimelli 1996].

${ }^{65}$ Letters from Hurwitz to Bianchi are published in [Bianchi 1959], p. 74-110 and stop in 1906. The above quote is on p. 89 .

66 "Riguardo ai tedeschi, il mio pensiero è sempre lo stesso; anzi, se è possibile, li odio più di prima, in ragione dei misfatti accumulati durante questa orribile guerra. Che finiranno per pagarli cari è la mia ferma speranza, ed anche la persuasione" (Bianchi to Volterra, 3 March 1915,VA:UDL).
} 
more years, it is clearly impossible to have personal relationships with the Germans; but I would like things to organized in such a way as to ease rather than impede scientific, and especially mathematical, exchanges. I think you share my opinion and hope that the resolutions of the Congress will ease a task that is already difficult in itself and that it is better not to embitter. This could only succeed in harming the interests for which we especially care. ${ }^{67}$

These examples show that, Volterra's opinion notwithstanding, Italian mathematicians' attitude toward ostracism was rather nuanced. Most indeed found it challenging to manage their relationships with their German and Austrian colleagues and everyone had to find the personal solution that fitted his own conscience and circumstances. But on the whole, we may say that Volterra's line nevertheless prevailed not only at a moral level, but also at the level of the institutionaization of Italian mathematics in the interwar period. We now turn to innovative scientific institutions established in interwar Italy by Volterra and Picone.

3.2. The Birth of the National Research Council. As noted earlier, the links between science, industry and the military seems to have been weak in Italy before 1914, especially when compared with other western nations. But in every country the war led scientists to increase their involvement in society. In 1937 Arnaud Denjoy (1884-1974) gave a speech at the Réunion Internationale des Mathématiciens that provides a good account of this postwar trend:

The prestige of science was increased by the war. This is a bitter consideration. But the splendid benefit it had previously generously granted men had moved them much less than the ruins and disasters that were lavished with profusion on the people of Europe by science-rooted technology. Hitherto indifferent and disdainful with respect to science in its useful and benevolent guise, humanity was seized by consideration and respect in front of the science that generated terrible and fatal effects. [...]

Innovation lay in the conception of scientific research seen as an independent public service, whose funding from the state was justified by its object alone, without having to complement it with the practicalities of definite applications. On its side, private enterprise has also distributed much more than before [to scientific research] ([Denjoy 1939], p. 2-3).

When Denjoy pronounced these words, Italy was under Fascist rule and had entered an official regime of economic and intellectual "autarchy." But just after the war, it seemed to be to be the perfect embodiment of the views expressed by

67 "Tu sai quanto io sia avverso ai tedeschi che hanno conciato il mondo in questa bella maniera, che ai vecchi come me non sarà dato di vedere tempi migliori! Però io credo che, nell'interesse stesso della scienza, convenga piuttosto attenuare se è possibile, le ostilità, e non dare loro l'ostracismo nei riguardi della produzione scientifica. Per ora, e per molti anni ancora, è evidentemente impossibile avere coi tedeschi relazioni personali; però io amerei che le cose si mettessero in modo da facilitare anziché ostacolare lo scambio di tutto quanto riguarda la produzione scientifica, in particolare la matematica. Credo che anche tu sarai dello stesso parere, e spero che le risoluzioni del Congresso saranno per facilitare un compito già arduo per sé e che non conviene inasprire. Ciò non potrebbe che riuscire a danno degli interessi che ci stanno massimamente a cuore" (Bianchi to Volterra, 2 March 1920, VA:ADL). 
Denjoy. At the first meeting of the Italian Society for the Progress of Science (SIPS) to take place after the war, in Trieste in 1921, the physicist Orso Mario Corbino (1876-1937) who was behind the exceptional school of physics founded by Enrico Fermi in Rome delivered an inspirational speech in his quality of minister of Public Instruction:

Among those to whom we should express our gratitude, let us also include science students and school teachers. Even though the technical deficiencies of Italian schools are at all levels significant, no one can deny its educational efficiency in the face of the admirable example set by the Italian youth on the battlefield. All social classes covered themselves with glory during the war, but in no other class was the disregard for danger and death so great and serene as in our student body. [...]

Behind the heroic soldiers, ever more arms and resources was produced by Italian industry which was conferred more power due to its closer links with scientists. And the whole country became engaged in the pursuit of scientific progress, whose extreme importance they now felt.

But, if science was the primordial factor in the Entente's victory thanks to its powerful means of destruction, the world should not forget that science alone has the power to heal it from the terrible ruins brought by the war [...]. And science will be able, I believe, to repair the damages that it was forced to inflict to bring about the triumph of justice in the world. ${ }^{68}$

An even more destructive war that broke out less than twenty years later was to show that Corbino was dreadfully mistaken. But on the moment, it was nice to believe in Corbino's speech. Volterra, like Corbino, wished to believe in the positive value of science. Volterra's scientific and political stature emerged much reinforced from WWI. In what we have called the Interlude period, between August 1914 to May 1915, he had strongly come out in favor of Italian intervention and when Italy joined the struggle ont the side of the Allies, he had heavily invested himself in military activities, in war-related scientific research, and above all in the promotion of cultural initiatives meant to strengthen the social implication of science beyond military applications. In 1916 he had for example founded the Italian Association

68 "E fra coloro cui va rivolta la nostra gratitudine, consentite che io comprenda anche $i$ cultori della scienza e $i$ docenti della scuola. Per quanto siano notevoli le deficienze tecniche della scuola italiana nei suoi vari ordini, nessuno può contestare la sua efficacia educativa, dopo l'esempio mirabile offerto dalla gioventù italiana sui campi di battaglia. Tutte le classi sociali si sono nel lungo cimento coperte di gloria, ma in nessuna, come nella classe degli studenti, fu cosi grande e sereno il disprezzo del pericolo e della morte. L'esempio del grande maestro, di Giacomo Venezian, non fu vano; e non fu inutile il sacrificio di Adolfo Viterbi, di Luciano Orlando, di Ruggiero Torelli, di Eugenio [Elia] Levi.

Dietro gli eroici combattenti apprestava armi e risorse sempre nuove l'industria italiana, che senti di colpo la potenza derivante da un più stretto contatto con gli uomini di scienza. E a favorire il progresso della scienza, di cui si intui la estrema importanza, si svolse con slancio tutto il paese.

Ma, se la scienza fu il fattore primo della vittoria dell'Intesa, e intervenne con l'ausilio dei suoi potenti mezzi di distruzione, il mondo non deve dimenticare che solo la scienza può risanarlo delle spaventevoli rovine che la guerra richiese [...]. E la scienza saprà, io ne ho fede, riparare $i$ danni che ha dovuto produrre per il trionfo della giustizia nel mondo" (our emphasis; souce???). 
for the Cooperation between Allied and Friendly Countries [Associazione italiana per l'Intesa fra i Paesi alleati e amici] in order to favor social, political, and cultural exchanges, as well as exchanges of teachers and students between institutions and universities of the Allied countries. Volterra was convinced that an industrialized country needed to tighten the interaction between science and industry. Science, in his view, had stopped to be the product of just a few scientists, as he pointed out in a speech he gave to honor Henri Poincaré at the Rice Institute in 1915: it was now a collective enterprise. And as such the developement of scientific research needed to be organized and coordinated on national and international levels.

Volterra had increased his personal stature as a mathematician as well. One might even say that it was even his own conception of mathematics that was reinforced by the war experience, since he had always been a fervent supporter of an abstract and highly innovative brand of mathematics that nevertheless always remained directed toward applications. In the $1920 \mathrm{~s}$, he was the main representative of Italian mathematics in most international organizations and meetings. His position in the Italian scientific community and his international network made him a natural reference point for military and state authorities with regards to the interactions with the scientific community.

It is therefore hardly surprising that, in the years 1918-1919, Volterra was the main Italian interlocutor of the British physicist Arthur Schuster (1851-1934), the Belgian astronomer Georges Lecointe (1869-1929), the American astronomer George Ellery Hale (1868-1938) and the French mathematician Picard in the promotion of IRC. IRC was a project concocted by Hale with a double objective: in the USA, IRC was to confer an international dimension to the National Research Council and would help turn it into a permanent institution; abroad, IRC would serve to export the American model and coordinate the refoundation of international scientific organizations around the scientists from victorious nations. IRC was moreover meant as a way of pursuing in peacetime the kind of intellectual and technoscientific cooperation that had taken place between the Allies. It would also develop the kind of international collaboration that used to characterize solar physics before the war, a field in which Hale had played a significant role. During the Inter-Allied Conference taking place in Brussels in July 1919, where Hale was confirmed as president of IRC, Volterra was elected vice-president, a position he kept until 1928.

In the immediate postwar period, Volterra thus assumed a major role on the international scientific scene. He was moreover appointed President of the International Bureau of Weights and Measures [Bureau international des poids et mesures], a position he kept until his death. Under Volterra's presidency, the general secretray was the Swiss Charles physicist Édouard Guillaume, who won the Nobel Prize in 1920. Under their lead, the seat of the Pavillon de Breteuil in Sèvres was expanded, thanks to funds coming from the Rockefeller Foundation (1929-1931) and new metrological units were established in electricity and photometry. Therefore, it is not surprising if Volterra's colleagues called him "Mr. Italian Science," (source???) a nickname which captures well his role and, at the same time, says something more about the weakness of Italian community which he represented.

In Italy, however, Volterra faced some setbacks when he tried to set up the National Research Council (CNR) as the Italian section of IRC. His project came 
to a halt due to the tensions we have already mentioned concerning Italians' attitude with respect to their colleagues from defeated nations. Political and social instabilities in postwar Italy also hindered Volterra's project. But CNR was not only the expression of the fundamental agreement between Volterra's views and international trends for reorganizing scientific research; it also represented the logical continuation of Volterra's directorship of the Officie for Inventions and Research (UIR) during WWI. In a letter dated 3 July 1919, the under-secretary of Arms and Munitions already informed Crocco that all documentans and instruments in possession of UIR when it was dissolved right after the war's end, were destined to the still non-existant CNR:

I am pleased to inform Your Lordship that I have ordered to close the service of [UIR] on 15 July, and that all scientific material, the library, the machinery and the furniture of the Office will be taken by this Institute [Crocco's Central Institute of Aeronautics], under the condition that everything shall be the property of the "National Research Council" once it will be established.

I do not think that difficulties can arise from this; in any case, I ask you to send me the remarks and suggestions you may have, especially regarding the liquid-air plant which has recently been seized in Trento and which will surely be ruined if inactive and regarding the completion and publication of the reports concerning nitrogen, zinc, pyrite ashes, potash, and other physical topics that [UIR] leaves in a state of near completion. ${ }^{69}$

While the establishment of CNR was facing resistance, Volterra had nevertheless succeeded in establishing the Italian MathematicalUnion (UMI) in the spirit of the Brussels conference that had instituted IRC. In other words, UMI was not not an expression of the Italian mathematical community (as in the case of other Italian professional societies, of physicists and chemists for instance), but the local branch of the International Mathematical Union. ${ }^{70}$

Finally approved in 18 November, 1923, the statutes of CNR underscores its national role: it was asked to coordinate and rationalize research activities by developing special fields; to be in touch with various national institutions regarding scientific questions; and to manage or to institute research laboratories. ${ }^{71}$ On 12

69 "Mi pregio comunicare alla S. V. di aver disposto che l'Ufficio Invenzioni e Ricerche cessi le sue funzioni dal 15 corrente, e che tutto il materiale scientifico, la biblioteca, l'archivio, il macchinario ed $i$ mobili dell'Ufficio medesimo vengano presi in consegna da codesto Istituto, con la condizione che quando sarà costituito il 'Consiglio Nazionale di Ricerche' tutto quanto sopra passerà in proprietà del Consiglio medesimo.

Non credo che potranno esservi difficoltà per questo; ad ogni modo prego presentarmi le opportune osservazioni e proposte: in modo speciale per quello che riguarda l'impianto per aria liquida di recente catturato a Trento, impianto che certo si deteriorerebbe se rimanesse inoperoso; e per quello che riguarda la ultimazione e la pubblicazione a stampa delle relazioni relative all'Azoto, allo Zinco, alle ceneri di Pirite, alla Potassa, nonché di alcune altre sopra argomenti di Fisica che l'Ufficio Invenzioni lascia in corso di avanzata redazione" (the under-secretary of Arms and Munitions to Crocco, 3 July 1919; copy of the letter forwarded to Volterra by Crocco, $\mathrm{VA}: \mathrm{ADL}$ ).

${ }^{70}$ For the history of UMI see for example [Sansone 1974]. On Volterra's role more specifically see [Guerraggio \& Nastasi 2005], chap. 3.

${ }^{71}$ For the history of CNR and, in particular, its first years, see [Simili 1993] and [Paoloni \& Simili 2001]. 
January, 1924, Volterra was unanimously elected president of the CNR. This is perhaps the moment when his reputation reached its apex. A year before, he had been elected president of the Academy of Lincei, after spending three years as its vice-president. He was the grey eminence of UMI (the President was Salvatore Pincherle), which served as the mathematical committee of CNR, and was the most influential figure of the SIPS.

The statutes of CNR betrays its main promoter's wild hopes. Aimed at rationalizing and developing Italian scientific organizations, CNR positioned itself in competition with traditional academies while insisting on tightening its connections with the industrial world and encouraging public support for scientific research. To transform a system where scientific research was free from outside intervention (besides economic pressure), but also fragmented by the structure of the university network as well as by personal ambition, Volterra aimed at orientating scientific research towards the great problems by supporting the integration of science with productive society.

But the establishment of CNR turned out to be Volterra's last victory. Two years later, Volterra indeed broke with Mussolini's Fascist governement, leaving him to assume the role of the progressive but isolated old lion. ${ }^{72}$

3.3. The Foundation of the Institute for the Applications of Computing. We have already seen how during WWI Picone directed a team in charge of computing firing tables to be used in Alpine areas, which apparently were successfully put to use on the front. For his exceptional merits, Picone was promoted first to the rank of lieutenant and then of captain. Above all, as we have seen, his success in this domain had made him aware of the huge promises of numerical computations. This new awareness conditioned the rest of his professional life. Already during the war, Picone dreamed of a new institute where numerical analysis would be applied to experimental and technological research. Let us quote once more Picone's autobiography:

When the war ended, I returned to the university lecture halls, and even though I was immediately absorbed by the necessity of reconquering my position on the battlefield of pure science, which I had lost during the three years of the war, I never stopped thinking to mathematics as a powerful tool for the experimental sciences and for technology and to an organization of things which might allow the mathematician to intervene in a more opportune way in problems of strictly mathematical nature that had blocked the progress of these sciences and their applications, including industrial applications.

Already in these early years of reconquered peace - alas so transitory! - I was struck by the idea of creating an institute in which mathematicians, equipped with the most powerful numerical computating instruments, would be able to collaborate with experimental scientists and with technicians to reach concrete solution to their numerical problems. [...]

\footnotetext{
${ }^{72}$ Volterra remained an influential figure in the international community especially through his role in the Rockefeller Foundation where he supported projects for changing the seat of the Internation Bureau of Weights an Measure and for creating the Institut Henri Poincaré in Paris. On this see [Sigmund-Schultze 2001].
} 
Hence the use of calculators, even by the mathematician, hence the design of laboratories for the mathematician, who could no longer be portrayed as the abstract isolated thinker needing only paper and pencil for his work. The mathematician had to get out of his office and to mingle with the crowd of those who seek to unravel the mysteries of nature and win possession of hidden treasures.

Since those years, I have been advocating for my ideas with an inexhaustible tenacity among my friends and in my teaching, as well as in scientific and industrial circles. But these ideas progressed with extreme sluggishness! Today more than ever, the resistance of almost all mathematicians to their progress seems inexplicable ([Picone 1972], p. 9).

With "inexhaustible tenacity," Picone recalled, and it is true, but in his campain in favor of a computing institute he also showed that he was endowed with great foresight and political skills. In 1923, recounting to the members of the Circolo Matematico of Catania the part scientists had played in WWI, Picone concluded with a most lucid assessment of the future role of science and technology in wars: "We must think of the future! I hope that the warning I voice, even if it comes from my humble level, may reach high up: In a future war, the armies that will win will be those with the best technological preparation. Future wars will be wars among scientists [le future guerre saranno guerre fra scienziati] ([Picone 1934], p. 29). To reach as high up as the Italian government, Picone sent a copy of his speech to the "Duke of victory" Armando Diaz (1861-1928), minister of War of Mussolini's first government. ${ }^{73}$ But his time was yet to come.

In 1925 Picone moved to Naples, where he could create a small, one-chair institute with funds from the Bank of Naples [Banco di Napoli]. In his recollection he called it an "embryonic Institute of Calculus, equipped with machines of modest computing power, but sufficient to start the experiment" (source??? [Picone 1972]??? pages???) His first disciple was Renato Caccioppoli (19041959), who was immediately recognized as one of the best Italian analysts.

In 1932, when Picone accepted a chair in Rome, the small institute followed and was attached to CNR with the name of Institute for the Application of Computing (IAC). ${ }^{74}$ According to his long-helf beliefs, IAC was to develop projects of civil, mechanical, and electronic engineering to which to apply numerical analysis - and mathematics in general. It was to devise new methods for the solution of problems submitted to it as well as to contribute to the development of analysis itself. ${ }^{75}$ IAC was a hierarchical structure at whose head was a director. The director was assisted by a vice-director, some assistants and researchers, and about ten graduate calculators and draughtsmen. The success of IAC was quick and impressive - it was consulted by the ministries of Aeronautics, of the Army, and of the Navy and

\footnotetext{
${ }^{73}$ Diaz' answer, dated 23 April 1923, is reproduced by Picone in the reprint of his speech [Picone 1934].

${ }^{74} \mathrm{On}$ the history of IAC, see [Nastasi 2006], as well as the accounts of its founder [Picone 1938] and [Picone 1953]. On Picone's engagement in numerical computations, see [Fichera 1986].

${ }^{75}$ See [Picone 1968] and Picone, "Sulla necessità per il progresso delle Scienze sperimentali e matematiche della creazione di un Istituto Centrale di Calcolo," unsigned report in the name of the "Comitato Matematico del CNR," 1929 (INAC Archives, Rome).
} 
it launched collaborations with various industrial firms in civil engineering and electric production. Around fifty contracts of consultancy on average were signed every year. Activities at IAC gave rise to about 250 publications during the period 1927-1940 covering many different fields, such as pure analysis, numerical computation, rational mechanics, civil engineering, the theory of elasticity, hydrodynamics, aerodynamics, etc. On an administrative level, IAC, where scientific research was organized outside the academic environment, was a great innovation on the Italian mathematical landscape. It was able to hire young mathematicians by creating various professional positions. Mathematics (both pure and applied) had entered the world of consulting.

Picone's extraordinary skills as teacher and manager were essential for IAC's success, but he also was an innovative researcher. For the first time on the Italian mathematical stage, numerical approaches became prominent. To Picone, the proof of an existence theorem and of the uniqueness of the solution were not enough. Now new constructive procedures for computing explicit solutions were to be devised. In other words, to find the numerical algorithm, to prove its convergence, and to compute the approximate error were now fundamental questions to be treated with at the highest level of rigor. Of course, Picone was not the first to face similar questions (not even in Italy). However, he was the first mathematician who explicitly took on problems emerging from other fields and to gather in the same institute different competences coming from various branches of pure, applied, and computational mathematics.

Picone's success - it must be emphasized - owed much to his unwavering support to the Fascist regime and to his close connection to the military establishment. ${ }^{76}$ The institute was well known and appreciated by high Fascist authorities who supported it financially. In this connection, Picone wrote in 1938 to the president of CNR, to whom he presented IAC's scientific activity: ${ }^{77}$

The highest task for [Italy's] autarchy assigned by the Duce to $[\mathrm{CNR}]$ can be faced if the mathematical instrument provides industries with procedures not only for the minimizing of materials used in construction without compromising stability and power, but also for the maximizing of time savings.

[...] [T] echnician canot be requested to have the high mathematical skills on which the computations required by the task mentioned above are based; in the present Institute, the technician may thus find the scientific assistance and the full understanding of his needs and objectives. [...]

Industial technical offices must not fear that this collaboration might erode their own importance and necessary autonomy; on the contrary, once the adequate computing method for a special purpose has been established [...], this method will remain in their exclusive possession; absolute discretion about the method will be kept by the Institute; and industrial technicians will be freely able

\footnotetext{
${ }^{76}$ In a letter to Gentile (5 June 1923) Picone warmly congratulated him for his adhesion to the regime which, he wrote, would pour "new pure blood into the robust veins of the Party that has rebuilt and renewed the country" (quoted in [Guerraggio \& Nastasi 1993], p. 185).

${ }^{77}$ Picone's unpublished report here quoted is to be found in the INAC Archives, Rome.
} 
to apply the method or modify it in any way the company will think beneficial. [...]

A large part of the research carried out by the Institute comes from the ministries of national defense: the stability of aeronautic appartuses, aerial bombing, stabilization instruments for underwater torpedoes, the firing of artillery at great distances, military radio communications, etc., all have provided ground for long and laborious researches, completed successfully with the help of the mathematical resources and the numerical computational means that belong to the Institute.

And the National Institute for the Application of Calculus, which is today at the orders of His Eminence, Marshal of Italy Pietro Badoglio, aims at maintaining its efficiency sound and even increasing it, also in order to be always able to answer the call for power of Italian arms. ${ }^{78}$

Picone adhered to all aspects of the Fascist ideology without exceptions - including racial laws. He took part in the UMI meeting in December 1938 when the Italian mathematical community as a whole decided to accept Fascist racial policy. Right after the meeting, Picone wrote Wacław Sierpiński (1882-1969) to point out that it was "pressing" that Aryan scientists worked together to show that science could progress without Jewish participation. Picone also mentioned the Academy of Lincei "where the percentage of Jewish members is very high." 79 Picone nevertheless offered unmistakable tokens of friendship and support for the Jewish mathematicians Fubini, Alessandro Terracini (1889-1968), and Guido Ascoli (1887-1957). Picone's faith in the regime and in the Duce was so strong that he refuse to cancel a joint lecture series with Fabio Conforto (1909-1954) in Germany during the month of July 1943. It is possible that he reached Italy back on the very

\footnotetext{
78 "L'altissimo compito autarchico assegnato dal DUCE al Consiglio Nazionale delle Ricerche può essere affrontato, se, da parte delle industrie, si richiede anche allo strumento matematico di pervenire a ridurre al minimo il materiale impiegato nelle costruzioni, senza comprometterne la stabilità e la potenza, conseguendo altresì tutta la possibile economia di tempo.

D'altra parte non è da richiedere al tecnico il possesso di quelle elevate cognizioni matematiche che sono di fondamento ai calcoli che impone il compito ora accennato, onde la creazione di questo Istituto nel quale il tecnico potrà trovare tutta l'assistenza scientifica possibile e la piena comprensione delle sue necessità e delle sue mete. [...]

Gli uffici tecnici delle industrie non possono temere la collaborazione indicata come tendente a sminuirne l'importanza e l'autonomia necessaria, anzi, una volta stabilito il metodo di calcolo adatto per le particolari ricerche nell'indirizzo sopraddetto, tale metodo, con la più assoluta riservatezza da parte dell'Istituto, sarà di loro completa proprietà e potrà essere liberamente applicato e modificato a puro ed unico vantaggio del successo della missione ad essi affidata nell'industria alla quale appartengono. [...]

Molta parte delle ricerche compiute dall'Istituto provengono dai Ministeri della difesa nazionale: la stabilità delle costruzioni aeronautiche, il tiro di bombardamento da aereo, gli apparecchi di stabilizzazione del siluro subacqueo, il tiro delle artiglierie a grandi distanze, le radio-comunicazioni militari, ecc., hanno fornito materia di lunghe e laboriose ricerche, felicemente condotte a termine, con l'ausilio dei mezzi matematici e di calcolo numerico in possesso dell'Istituto.

E l'Istituto Nazionale per le Applicazioni del Calcolo, oggi agli ordini di S. E. il Maresciallo d'Italia Pietro Badoglio, si propone di mantenere integra ed in aumento la propria efficienza anche per poter sempre rispondere a qualsiasi appello per la potenza delle armi italiane" (ibid., INAC Archives, Rome).

${ }^{79}$ This letter was published published in [Guerraggio et al. 2007], p. 57-58.
} 
day the Fascist regime fell on 8 September. Immediately, Picone distanced himself from the regime and started to convert "his" institute for peaceful work. But this is another story [Nastasi 2006].

\section{Conclusion}

We hope to have thrown some light on Italian mathematicians' role of in World War I - a subject that had hitherto almost completely escaped the attention of historians. We have argued that most of Italian mathematicians played a clear and unambiguous role: politically they were against the Central Empires from August 1914 to the early 1920s even when Italy was not yet or no longer at war with them, and they soon took side with the Entente arguing for Italian intervention, developing scientific collaborations with scientists from Allied nations, and enforcing the ban decided by international scientific organization in 1918. This was the case of Volterra, Picone, Castelnuovo, Enriques, Severi, and many others. As we documented, nobody in the mathematical community was as strongly involved as Volterra in favor of an Italian intervention in the war on the side of France, England, and Russia.

But other mathematicians (such as Levi-Civita and Segre) showed a different attitude and did not want Italy to enter the war. The polemics between supporters of Italian intervention and neutralists - called with contempt 'Germanophiles" was harsh. However, when war was declared all of them, either in favor of and opposed to intervention, joined together for the defense of the fatherland - with the sole exception, as far as we know, of Levi-Civita who remained a commited pacifist. Segre's case is emblematic: considered a Germanophile before the war broke out, he soon addressed a moving letter to Volterra expressing his deep nationalistic feeling that he concluded by the call: "Viva l'Italia". ${ }^{80}$

During the war, mathematicians fought in the Italian Army (generally as officers) to defend their country and often became close collaborators of military organizations. We have in particular seen how both Volterra and Picone, respectively, created two institutions attached to the Ministry of War: the Office for Inventions and Research (UIR) and the Ballistic Office attached to the Sixth Army. For both of them, the war experience was fundemental and life-changing: it showed them the way in which closer link between mathematics, science, industry, and the military were to be woven. In the interwar period, such experience was drawn upon to establish new institutions: CNR for Volterra and IAC for Picone. Both institutions can, as we have seen, be interpreted as the natural continuation of their war work.

After the war another polemic arose in Italy between the promoters of ostracism against German and Autrian science and those who wanted to reintegrate German scholars in international meetings and organizations. In Italy, supporters of intervention were logically for the most part in favor of ostracism. In his 1920 Saggi scientifici, Volterra reprinted some of his well-known lectures held at the International Congresses of Paris (1900) and Rome (1908) [Volterra 1920]. In this reprint, he carefully erased all references to German mathematicians, including the name of Felix Klein. ${ }^{81}$ Other mathematicians had a more international spirit and wished to reestablish scientific collaboration with Germany. Among them, Levi-Civita played a large part in the creation of the International Congresses of

\footnotetext{
${ }^{80}$ Segre to Volterra, 27 May 1915,VA:ADL.

${ }^{81}$ More on this in [Guerraggio \& Nastasi 2008], p. 143.
} 
Applied Mechanics with German colleagues. Similarly, De Franchis refused to exclude German mathematicias from the Mathematical Circle of Palermo.

In the spring of 1914, an international meeting took place in Palermo for the celebration of the thirty-year anniversary of the Mathematical Circle, organized mainly by Segre and Volterra. Many illustrious mathematicians and physicists partook in the celebrations spending a week together in Palermo, most of them coming from Germany, France and, of course, Italy (Do we have names???). About one month later, war tore down personal and scientific relationships generally for many years. Many of them would resume these relationships with the "enemy" only in the International Congress of Mathematicians in Bologna in 1928, fourteen years later. This may serve to underscore the absurdity of WWI.

\section{References}

[Albers et al. 1986] Donald Albers, G. L. Alexanderson, \& Constance Reid, International Mathematical Congresses: An Illustrated History, 1893-1986, Springer, New York, 1986.

[Amaldi \& Levi-Civita 1923-1927] Ugo Amaldi \& Tullio Levi-Civita, Lezioni di Meccanica Razionale, 2 vols., Zanichelli, Bologna, 1923-1927.

[Amaldi \& Levi-Civita 1935] Ugo Amaldi \& Tullio Levi-Civita, Nozioni di balistica esterna, Zanichelli, Bologna, 1935.

[Anderson 1997] John David Anderson, A History of Aerodynamics and Its Impact on Flying Machines, Cambridge University Press, Cambridge, 1997.

[Apollonio 1973] Umbro Apollonio, ed., Futurist Manifestos, trans. Robert Brain, R. W. Flint, J. C. Higgit, \& Caroline Tisdall, Viking Press, New York, 1973.

[Aubin forthcoming a] David Aubin, "Audacity or Precision": The Paradoxes of Henri Villat's Fluid Mechanics in Interwar France, paper presented at a "Workshop on the History of Fluid Mechanics", Rauischholzhausen, 15-18 October, 2006. To appear. (exact citation???)

[Aubin forthcoming b] David Aubin, L'élite sous la mitraille : mathématiciens, mémoire et oubli de la Grande Guerre, manuscript submitted to the Revue d'histoire des mathématiques.

[Aubin \& Bret 2003] , David Aubin et Patrice Bret, eds., Le Sabre et l'éprouvette: l'invention d'une science de guerre, 1914-1939, "14-18 Aujourd'hui," Agnès Viénot, Paris, 2003.

[Battimelli 1996] Giovanni Battimelli, Tullio Levi-Civita e i congressi internazionali di meccanica applicata, Rivista di Storia della Scienza 4 (1996), p. 51-80.

[Beaulieu 2009] Liliane Beaulieu, Regards sur les mathématiques françaises entre les deux guerres. Introduction, Revue d'histoire des sciences 62-1 (2009), p. 9-37.

[Bianchi 1922] First name??? G. Bianchi, Corso di Balistica esterna, Publisher???, Torino, 1922.

[Bianchi 1959] Luigi, Bianchi Opere, vol. 11: Corrispondenza, ed. UMI \& CNR, Edizioni Cremonese, Roma, 1959.

[Booß-Bavnbek \& Høyrup 2003] Bernhelm Booß-Bavnbek \& Jens Høyrup, eds., Mathematics and War, Birkhäuser, Basel, 2003.

[Brigaglia \& Masotto 1982] Aldo Brigaglia \& Guido Masotto Il Circolo Matematico di Palermo, Dedalo, Bari, 1982.

[Chisini 1918] Oscar Chisini, Telemetro logaritmico 'Chisini'. Istruzioni sui telemetri a larga base Complete reference???.

[Collective 1918] Collective, Onoranze a Luciano Orlando, Ruggiero Torelli, Eugenio Elia Levi, Adolfo Viterbi, professori di matematica nelle Università italiane caduti in guerra, Seminario Matematico della Facoltà di Scienze dell'Università di Roma, 22 June 1918.

[Collective 1961] Collective, Vito Volterra nel I centenario della nascita, in Roma, Accademia Nazionale dei Lincei, Problemi Attuali di scienza e di cultura 51 (1961).

[Crocco 1961] Arturo Crocco, Conference Celebrating the First Centenary of Volterra's Birth, Accad. Naz. Lincei, 51 (1961), Roma, pages???.

[Croce 1950] Benedetto Croce, L'Italia dal 1914 al 1918. Pagine sulla guerra, Laterza, Bari, 1950.

[Dauben 1980] Joseph W. Dauben, Mathematics and World War I: The International Diplomacy of G.H. Hardy and Gösta Mittag-Leffler as Reflected in Their Personal Correspondence, Historia Mathematica 7 (1980), p. 261-288. 
[D'Adhémar 1934] Robert D'Adhémar R. La balistique extérieure, Mémorial des sciences mathématiques 65, Gauthier-Villars, Paris, 1934.

[De Maria \& Seidel 1980] M. De Maria \& R. W. Seidel, Lo scienziato e l'inventore: l'inizio dell'integrazione sistematica fra scienza e industria in USA durante la prima guerra mondiale, Testi \& Contesti 4 (1980), p. 5-32.

[Denjoy 1939] Arnaud Denjoy, Aspects actuels de la pensée mathématique, Bulletin de la Société Mathématique de France 67 (1939), p. 1-12

[Dieudonné 1978] Jean Dieudonné, Abrégé d'histoire des mathématiques: 1700-1900, 2 vols., Hermann, Paris, 1978.

[Dieudonné 1981] Jean Dieudonné, History of Functional Analysis, North Holland, Amsterdam, 1981.

[Fabu 1994] Lucio Fabi Gente di trincea, Mursia, Milano, 1994.

[Fichera 1978] First name??? G. Fichera Mauro Picone, Atti dell'Accademia delle Scienze di Bologna (13) 5 (1978), p. 245-263.

[Fichera 1986] First name??? G. Fichera, Mauro Picone, un pioniere dell'analisi d'oggi, in Atti del Convegno celebrativo del centenario della nascita di Mauro Picone e di Leonida Tonelli (Roma, 6-9 maggio 1985), Publisher, City???, p. 75-88.

[Fieschi 1987] Roberto Fieschi, Scienza e guerra, Editori Riuniti, Rome, 1987.

[Fieschi \& Paris De Renzi 1995] Roberto Fieschi \& C. Paris De Renzi, Macchine da guerra: gli scienziati e le armi, Einaudi, Turin, 1995.

[Filippi 1919] First name??? G. Filippi, Le Università e gl'Istituti d'istruzione superiore in Italia durante la guerra, Bollettino ufficiale del Ministero della Pubblica Istruzione 47 (1920), p. 329384 .

[Fontanon 2003] Claudine Fontanon, Paul Painlevé et l'aviation : aux origines de l'étatisation de la recherche scientifique, in Paul Painlevé (1863-1933): un savant en politique, ed. by Claudine Fontanon \& R. Frank, Presses Universitaires de Rennes, Rennes, p. 41-56.

[Fontanon 2010] Claudine Fontanon, La carrière scientifique de Gustave Eiffel : un parcours méconnu en aérodynamique (1892-1922), in Les centraliens, ed. by J. L. Bordes, Presses universitaires de France, Paris, pages???.

[Fontanon forthcoming] Claudine Fontanon, Paul Painlevé, le savant, l'homme politique et les mathématiciens russes (1914-1923), in [Goldstein forthcoming], forthcoming.

[Gibelli 1998] Antonio Gibelli, La Grande Guerra degli italiani, 1915-1918, Sansoni, Florence, 1998.

[Goldstein 2009] Catherine Golstein, La théorie des nombres en France dans l'entre-deux-guerres : de quelques effets de la première guerre mondiale, Revue d'histoire des sciences 62-1 (2009), p. $143-175$.

[Goldstein forthcoming] Catherine Golstein, ed., Mathématiciens français à travers la première guerre mondiale, forthcoming.

[Goodstein 2007] Judith R. Goodstein, The Volterra Chronicles: The Life and Time of an Extraordinary Mathematician (1860-1940), American Mathematical Society,Providence \& London Mathematical Society, London, 2007.

[Gratzer 2000] Walter Bruno Gratzer The Undergrowth of Science: Delusion, Self-deception, and Human Frailty, Oxford University Press, Oxford \& New York, 2000.

[Guerraggio et al. 2007] Angelo Guerraggio, Maurizio Mattaliano \& Pietro Nastasi Mauro Picone e $i$ matematici polacchi: 1937-1961, Accademia Polacca delle Scienze, Roma, 2007.

[Guerraggio \& Nastasi 1993] Angelo Guerraggio \& Pietro Nastasi, Gentile e i matematici italiani: Lettere 1907-1943, Bollati Boringhieri, Turin, 1993.

[Guerraggio \& Nastasi 2005] Angelo Guerraggio \& Pietro Nastasi, Italian Mathematics Between the Two World Wars, Birkhäuser, Basel, 2005.

[Guerraggio \& Nastasi 2008] Angelo Guerraggio \& Pietro Nastasi, Roma 1908: il Congresso Internazionale dei Matematici, Bollati Boringhieri, Turin, 2008.

[Guerraggio \& Paoloni 2008] Angelo Guerraggio \& Giovanni Paoloni, Vito Volterra, Franco Muzzio Editore, Rome, 2008.

[Hartcup 1988] Guy Hartcup, The War of Invention: Scientific Developments, 1914-18, Brassey's, London, 1988.

[Isnenghi 1989] Mario Isnenghi, Il mito della Grande Guerra, Il Mulino, Bologna, 1989.

[Isnenghi 1993] Mario Isnenghi, La Grande Guerra, Giunti-Casterman, Florence, 1993. 
[Isnenghi 1996-1997] Mario Isnenghi, I luoghi della memoria, 3 vols., Laterza, Rome \& Bari, 1996-1997.

[Isnenghi \& Rochat 2000] Mario Isnenghi \& Giorgio Rochat, La Grande Guerra 1914-1918, La Nuova Italia, Florence, 2000.

[Lacaita 2007] Carlo G. Lacaita, Università e impresa, Annali di Storia delle Università Italiane, 12 (2007), pages???.

[Landogna 1937] Francesco Landogna, ed., Corso di Cultura Militare, 3 vols., Morano Editore, Naples, 1937.

[Lehto 1998] Olli Lehto, Mathematics without Borders: A History of the International Mathematical Union, Springer, New York, 1998.

[Leloup 2009] Juliette Leloup, L'entre-deux guerres mathématique à travers les thèses soutenues en France, doctoral thesis, Université Pierre et Marie Curie, Paris, 2009.

[Levi-Civita 1906] Missing reference ???

[Luchaire 1965] Julien Luchaire, Confession d'un français moyen, 2 vol., Olshki, Florence, 1965; repr. from first ed. Sagittaire, Marseille, 1943.

[MacMillan 2001] Margaret Mac Millan, Peacemakers: The Paris Conference of 1919 and Its Attempt to End War, J. Murray, London, 2001.

[Mazliak \& Tazzioli 2010] Laurent Mazliak \& Rossana Tazzioli, eds., Mathematicians at War: Volterra and his French Colleagues in World War One, Springer, New York, 2009.

[Nastasi 2006] Pietro Nastasi, I primi quarant'anni di vita dell'Istituto per le Applicazioni del Calcolo "Mauro Picone", Bollettino dell'Unione Matematica Italiana, sez. A., volume (2006), pages???.

[Nastasi \& Tazzioli 2000] Pietro Nastasi \& Rossana Tazzioli, eds., Aspetti scientifici e umani nella corrispondenza di Tullio Levi-Civita (1873-1941), Quaderni Pristem 12, Palermo, 2000.

[Paoloni \& Simili 2001] Giovanni Paoloni \& Raffaella Simili, eds., Per una storia del Consiglio Nazionale delle Ricerche, 2 vols., Laterza, Rome \& bari, 2001.

[Paoloni \& Simili 2008] Giovanni Paoloni \& Raffaella Simili, Vito Volterra and the Making of Research Institutions in Italy and Abroad, in The Migration of Ideas, ed. by R oberto Scazzieri \& Raffealla Simili, Science History Publications, Sagamore Beach, p. 123-150.

[Pestre 1990] Dominique Pestre, La première guerre mondiale et ses conseguences sur la science en France, Talk delivered the Conference on "Scienza, Tecnologia, Istituzioni in Europa (19001920): Vito Volterra e l'origine del CNR," Rome, 27-28 November, 1990.

[Picone1917] Mauro Picone, Sul tiro dei medii e dei grossi calibri in montagna, Rivista dell'Artiglieria e Genio 35 (1917), p. 5-15

[Picone 1934] Mauro Picone L'Artiglieria italiana nella guerra mondiale, Tipografia del Senato di G. Bardi, Rome; repr. of a lecture held in Catania in 1923 and first publ. in Esercitazioni di Matematica del Circolo Matematico di Catania 3 (1923), p. 1-31.

[Picone 1938] Mauro Picone L'Istituto Nazionale per le Applicazioni del Calcolo nel quadriennio 1933/37, Pubbl. dell'INAC 27 (1938).

[Picone 1953] Mauro Picone, Sull'opera matematica dell'Istituto Nazionale per le Applicazioni del Calcolo nel decorso quarto di secolo della sua esistenza, Atti del IV Congr. dell'U.M.I. (Taormina, 25-31 October 1951), vol. 1, p. 27-44.

[Picone 1956] Mauro Picone, Commemorazione di Vito Volterra pronunciata a Palermo il 15 settembre 1956, cinquantesimo anniversario della Società Italiana per il Progresso delle Scienze, Ricerca Scientifica 26 (1956), p. 3277-3289.

[Picone 1964] Mauro Picone, Commemorazione di Antonio Signorini, Atti e Memorie dell'Accad. Petrarca di Lettere Arti e Scienze di Arezzo 37 (1958-1964), p. 378-402.

[Picone 1967] Mauro Picone, Presentazione di pubblicazioni dovute alla guerra 1915-1918, Rendiconti delle sedute della Cl. Sci. Fis. Mat. Natur. Accad. Lincei 42 (1967), fasc. 1, 7. p.

[Picone 1968] Mauro Picone, Presentazione di pubblicazioni riguardanti l'attività dell'Istituto per le Applicazioni del Calcolo, dal 1927, anno della sua fondazione, al 1960, in cui fu sottratto alla direzione del suo ideatore, Rendiconti dell'Accademia dei Lincei 44(4) (1968), p. 1-10.

[Picone 1971] Mauro Picone L'Artiglieria italiana nella prima guerra mondiale, in Conferenze 1970-1971, Scuole di Applicazione (Turin), 1971, p. 67-98.

[Picone 1972] Mauro Picone, La mia vita, Bardi, Rome, 1972.

[Picone 1974] Mauro Picone M. 1974. Discorso tenuto nel Convegno Internazionale per la celebrazione del centenario della nascita di Tullio Levi-Civita (17-19 dicembre 1973), Tip. Bardi, Rome, p. 20-22. 
[Picone \& Bilinski 1969] Mauro Picone \& B. Bilinski, Marie Sklodowska-Curie in Italia. Nel centenario della nascita (1867-1934), Ossolineum, Wroclaw, Warsaw \& Cracow, 1969.

[Renard 2002] First name??? I. Renard, "Il Grenoble": Il primo Istituto francese al mondo, Antologia Vieusseux 7 (2002), p. 1-30.

[Roussel 1989] Yves Roussel, L'histoire d'une politique des inventions: 1887-1918, Cahiers pour l'Histoire du CNRS 3 (1989), p. 19-57.

[Rusconi 2005] Gian Erico Rusconi, L'azzardo del 1915: come l'Italia decide la sua guerra, Il Mulino, Bologna, 2005.

[Sansone 1974] Giovanni Sansone, Le attività dell'Unione Matematica Italiana nel primo cinquantennio della sua fondazione, Bollettino dell'Unione Matematica Italiana 2 (1974), p. 7-43.

[Sansone 1977] Missing reference???.

[Schiavon 2003a] Martina Schiavon, Itinéraires de la précision : géodésiens, artilleurs, savants et fabricants d'instruments en France, 1870-1930 (environ), doctoral thesis, ÉHESS, Paris, 2003.

[Schiavon 2003b] Schiavon, Martina, Des savants-officiers entre science, armée, État et industrie de précision : les géodésiens du Service géographique de l'Armée, 1887-1920, in [Aubin \& Bret 2003], p. 60-73.

[Schroeder-Gudehus 1978] Brigitte Schroeder-Gudehus, Les scientifiques et la paix : la communauté scientifique internationale au cours des années 20, Les Presses de l'Université de Montréal, Montréal, 1978.

[Schwartz 2001] Laurent Schwarz, A mathematician grappling with his century, trans. Leila Schneps, Birkhäuser, Basel \& Boston, 2001.

[Siacci 1888] Francesco Siacci, Balistica, Casanova, Turin, 1888.

[Sigmund-Schultze 2001] Reinhardt Sigmund-Schultze, Rockefeller and the Internationalization of Mathematics Between the Two World Wars, Birkhäuser, Basel \& Boston, 2001.

[Siegmund-Schultze 2003] Reinhardt Siegmund-Schultze, Military Work in Mathematics 19141945: An Attempt at an International Persective, in [?], p. 23-82.

[Signorini 1919] First name??? A. Signorini Un teorema di confronto in Balistica esterna e alcune sue applicazioni, Rendiconti del Circolo Matematico di Palermo 43 (1919), p. 357-393.

[Signorini 1922] First name??? A. Signorini, Sulla velocità minima, Rendiconti dell'Accademia Nazionale dei Lincei 31(2), p. 101-104.

[Simili 1993] Raffealla Simili, ed., Scienza, tecnologia e istituzioni in Europa, Laterza, Bari, 1993.

[Tanzi Cattabianchi 1977] Luigi Tanzi Cattabianchi, I contributi di Mauro Picone alla Balistica razionale, Rivista Matematica dell'Università di Parma 3 (1977), p. 357-389.

[Tanzi Cattabianchi 1981] Luigi Tanzi Cattabianchi, I contributi di Guido Fubini e di Francesco Severi ad alcuni problemi di balistica esterna, Atti dell'Accademia delle Scienze di Torino, Cl. Sci. Fis. Mat. Natur. 115 Suppl. (1981), p. 217-233.

[Tanzi Cattabianchi 1988] Luigi Tanzi Cattabianchi, I contributi di Vito Volterra alla balistica da aeromobili, Rivista Matematica dell'Università di Parma 14 (1988), p. 87-105.

[Tenca 1959] First name??? L. Tenca Matematici combattenti, Archimede 11(4) (1959), p. 186190.

[Teofilato 1920] First name??? P. Teofilato, Sulla determinazione dei centri sonori, Atti della Pontificia Accademia dei Nuovi Lincei 73 (1920), p. 185-189.

[Terracini 1968] First name??? A. Terracini, Ricordi di un matematico, Ediz. Cremonese, Rome, 1968.

[Tomassini 1995] First name??? L. Tomassini, L'Italia nella Grande Guerra, Fenice, Milan, 1995.

[Tricomi 1967] First name??? F. G. Tricomi, La mia vita di matematico attraverso la cronistoria dei miei lavori, Cedam, Padua, 1967.

[Tricomi 1977] First name??? F. G. Tricomi, Mauro Picone (1885-1977). Cenni commemorativi, Atti della Accademia delle Scienze di Torino 111 (1977), p. 573-576.

[Volterra 1916] Vito Volterra, Metodo di calcolo degli elementi di tiro per artiglieria aeronautica, Rendiconti dell'Istituto Centrale Aeronautico 5 (1916), pages???.

[Volterra 1920] Vito Volterra, Saggi scientifici, Zanichelli, Bologna, 1920.

[Weil 1992] André Weil, The Apprenticeship of a mathematician, transl. by Jennifer Gage, Birkhäuser, Basel \& Boston, 1992. 
ADDRESS???

E-mail address: xyz@math.university.edu???

Université de Lille-1, Laboratoire Paul Painlevé, U.F.R. De Mathématiques, 59655 Villeneuve D'AscQ Cedex, FRANCE

E-mail address: Rossana.Tazzioli@math.univ-lille1.fr 